\title{
Coping with Images of Initiations in the Mithras
} Cult

Indagare le immagini delle iniziazioni nel culto di Mitra

\section{Nicole Belayche}

\section{(2) OpenEdition \\ 1 Journals}

\section{Electronic version}

URL: https://journals.openedition.org/mythos/3029

DOI: $10.4000 /$ mythos.3029

ISSN: 2037-7746

\section{Publisher}

Salvatore Sciascia Editore

\section{Electronic reference}

Nicole Belayche, "Coping with Images of Initiations in the Mithras Cult", Mythos [Online], 15 | 2021,

Online since 15 December 2021, connection on 15 December 2021. URL: http://

journals.openedition.org/mythos/3029 ; DOI: https://doi.org/10.4000/mythos.3029

This text was automatically generated on 15 December 2021.

Mythos 


\title{
Coping with Images of Initiations in the Mithras Cult
}

\author{
Indagare le immagini delle iniziazioni nel culto di Mitra
}

Nicole Belayche

Nothing does more to reveal what was in the mind of the ancients ( $\tau \grave{\eta} v \tau \tilde{\omega} v \pi \alpha \lambda \alpha \imath \tilde{\omega} v \dot{\varepsilon} \mu \varphi \alpha$ ível

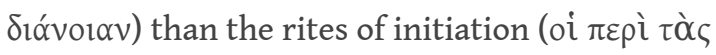
$\tau \varepsilon \lambda \varepsilon \tau \grave{\alpha} \varsigma$ ó $\rho \gamma 1 \alpha \sigma \mu o i)$ and the ritual acts ( $\tau \grave{\alpha}$

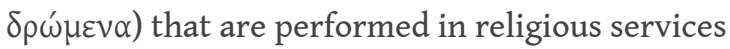

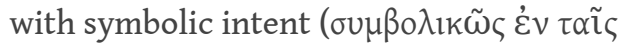
iepoupyíaı). Plutarch $^{1}$

1 "Religious Images in the Roman World": the topic that the editors set in this collection is indeed a key issue, for images and visuality were a daily lived experience in both the Greek $^{3}$ and the Roman world. ${ }^{4}$ Yet it is a highly demanding one in terms of method, the more so for those who seek to examine the images of the mystery cults, which are by definition placed under a ban of silence. In that respect, it might be worthwhile to start with the rather pessimistic position of R. Beck on the question of images in the Mithras cult: "as soon as we start to interpret the iconography, to say what it 'means', we enter the domain of error, or at least of potential error". ${ }^{5}$

2 This paper (which is not a nth study of the "mysteries of Mithras" as a whole) sets out to reconsider the ways in which one might narrow down "the domain of error" in investigating Mithraic images. ${ }^{6}$ All "mystery cults" share similar documentary problems; 7 yet the "mysteries" of Mithras are probably those that prove most complex when one turns the attention to the images and the message they convey. The expectations raised by a large body of visual evidence are great, ${ }^{8}$ if only because of the lack of other evidence for "mysteries" in the epigraphic testimonies of the worshippers themselves, ${ }^{9}$ and in the ancient literature alluded to by Porphyry and already stamped with a Platonic reading. ${ }^{10}$ The scholarly tradition goes back to Franz Cumont, who considered images as "notre source d'information principale dans l'étude du 
mithriacisme". ${ }^{11}$ Cumont viewed these images as "hiéroglyphes", ${ }^{12}$ able to reveal what he called the Mithraic "doctrine" and "liturgy" (a "Roman form of Mazdeism", to his eyes) through the symbolist approach that F. Creuzer had initiated. ${ }^{13}$ "Nous ne connaissons guère ces traditions épiques [those of the Mithras mysteries' doctrine] que par les monuments qui leur servaient d'illustration"; ${ }^{14}$ in other words, visual testimonies reveal the missing theology through a symbolic language..$^{15}$ Cumont had in mind the tauroctony (i.e. the reliefs of Mithras slaying the bull); $;{ }^{16}$ but the frescoes that could credibly be interpreted as images of initiation were discovered or published after the 1960s. However, Cumont's "literary" method of reading texts as pathways to the meaning of images ${ }^{17}$ is still applied in current readings of these frescoes, as we shall note below. Textual evidence on these "mysteries" come from philosophical and Christian works, which Cumont and later scholars took for granted, whatever their chronology may be ${ }^{18}$ and with little attention to the biases set by their intentionality upon the texts, whether didactic or polemical. ${ }^{19}$ Finally, the (seven) grades (sometimes) attested in both texts and images ${ }^{20}$ are taken for granted as evidence of initiation. ${ }^{21}$ Yet their meaning as either a hierarchical progression within the Mithraic communities or as actual successive new religious statuses after (metaphorical) journeys in the cosmos, is less certain than we should expect. ${ }^{22}$

By invoking various interpretative models, scholars shed light on different facets of what mystery cults could be. Two theoretical models are worth recalling for the purposes of this reflection on images of initiation in the Mithras cult. Starting from psychological expressions - like that of Aelius Aristides evoking the Eleusinian

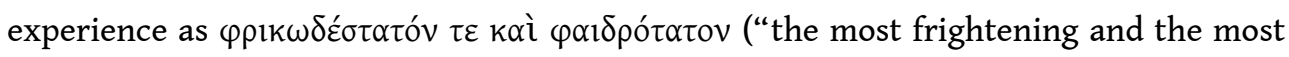
joyful" $)^{23}$ - cognitivist approaches focus on the sensorial and psychological data that trigger mental processes at work at individuals during the rituals, ${ }^{24}$ mainly during the "initiation", and they examine the epistemic phenomena that arise from them (acquisition, memorization, transformation). ${ }^{25}$ Do images mirror these feelings, and through which visual signs? Shifting from individuals to groups, sociological tools envision these cults in terms of collective identity (initiated-insiders / uninitiatedoutsiders) and hierarchical organization within the groups: what is reserved on the level of words (the $\lambda \varepsilon \gamma o ́ \mu \varepsilon v \alpha$ ), or things shown (the $\delta \varepsilon ı \kappa v v ́ \mu \varepsilon v \alpha$ ) to few "initiands / initiates" (with eventual progression to higher grades as in the Mithras cult) or to specific ritual agents ${ }^{26}$ - as in the various sequences of the many days festival of the Eleusinian Mysteries? ${ }^{27}$ Do images represent these groupings or functions, and how?

4 From the 1970s onwards, in the wake of Richard Gordon and Roger Beck, a joint social and astronomical reading of Mithraic iconographic "programs" has been developed, mainly based on the representations of the tauroctony - just like in Cumont's approach, albeit with a very different outlook. ${ }^{28}$ The semiotic reading of images provides scholars with a useful tool for investigating what images of mysteries, or rather images that scholars identify as representing mystery scenes, ${ }^{29}$ can tell us on the ritual practices within these secret cults. Even thirty-four years after the publication of Ancient Mystery Cults of Walter Burkert, ${ }^{30}$ these cults still prompt scientific debate, insofar as the term might already encompass a large range of conceptions in ancient Rome - from the possibility of an intimate relation with the divine (whatever the process may be) to any kind of spiritual knowledge that is not available through dialectic reasoning and the common ways of ritual interactions with the divine. ${ }^{31}$ 
5 After a number of studies on the images depicting rituals and the dialogue between textual and visual evidence, ${ }^{32}$ over the last five years I have been co-leading with Francesco Massa a research project on "mystery cults and their agents". ${ }^{33}$ We tackled many issues pertaining to mystery cults, among which that of images of mysteries. The following reflections on images of initiations in the Mithras cult owe much to this collective work with F. Massa and the colleagues who took part in the project. ${ }^{34}$ In light of their results, the aim of my contribution is more modest (much as the challenge remains difficult) ${ }^{35}$ : to focus on frescoes (and incidentally a vase) that were discovered in three mithraea (in Italy and Palestine) and were interpreted as images of initiatory rituals. I shall leave aside the tauroctony and its side panels, ${ }^{36}$ which are hardly related to narrative accounts of the god's "story" during ritual meetings ${ }^{37}$ and the exegetic commentaries that took shape on. ${ }^{38}$

\section{Outlining the Puzzling Question of Images of Mystery Cults}

6 I do not need to draw an overall picture of mystery cults, because the bibliography is already rich, ${ }^{39}$ although a number of pending questions justify ongoing work. ${ }^{40}$ Moreover the Mithras cult in the Roman empire holds a peculiar place in the list of mystery cults insofar as it was a Roman creation, probably devised in Rome itself in the last quarter of the first century CE. ${ }^{41}$ It thus has few common features with the Greek Eleusinian-type mysteries - as Cumont had already noted over a century ago: “Ce n'est pas à l'imitation des cultes helléniques que ses adeptes [scil. those of Mithras] constituèrent leurs sociétés secrètes" ${ }^{42}$ However, it is unavoidable to start with some remarks on the question of the images of mystery cults in general, for the cult of Mithras has been listed in this broad category since the birth of Mithraic studies at the end of the nineteenth century. ${ }^{43}$ Cumont envisioned "oriental"/mystery cults as a coherent religious category displaying common features: ${ }^{44}$ on the deities' side, their cosmic power made them saviour gods, ${ }^{45}$ while on the worshippers' side the initiates had privileged relations with the gods and access to reserved (mystikoi) revelations, and enjoyed a new life both hic et nunc and post mortem and, once initiated, enjoyed a new life. ${ }^{46}$ Such a "mystic" image of mystery cults was effectively deconstructed from the 1970s onwards. ${ }^{47}$ Yet scholars have invoked testimonies of Greek-type mystery cults (i.e. the model of traumatic experience) in support of their reading of what they regard as images of initiation in the Mithras cult, whatever its Roman 'invention'. ${ }^{48}$

7 Research on mystery cults in the Greek and Roman periods could be one of the dossiers in the field of the history of religions that benefitted most substantially from the iconic and visual turn, ${ }^{49}$ framed within the wider question of the representation of rituals. ${ }^{50}$ However, among all kinds of rituals, the mystery ones display two specific features, ${ }^{51}$ which set them as a special category and also carry consequences on the images of mysteries - for the purposes of this paper, those of Mithras. Firstly, mystery cults are

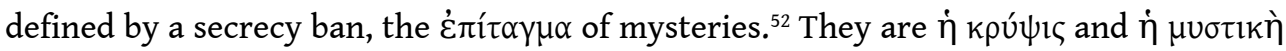

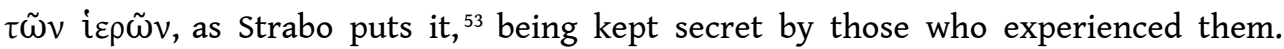
Actually there is no trace of "mysteries" in the inscriptions the Mithras' worshippers (the vexed question of the grades will be addressed later), neither in the lexicon nor in the clues of rituals. ${ }^{54}$ Secondly, according to the Eleusinian pattern, the experience the participants (mystai / initiands) lived during the ritual is regularly expressed as being 


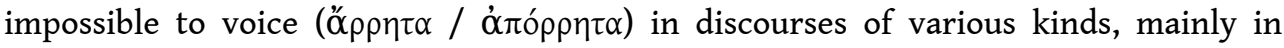
philosophical texts, but also in literary and epigraphical documents. ${ }^{55}$ Consequently, the ritual experience could be evoked, but it is never "described". The Greek authors who point out the epistemological nature of "mystery-related" experiences (with the Eleusinian model in mind) explained it as a specific kind of knowledge that Aristotle would have defined according to a fragment transmitted by a Byzantine (tenth century

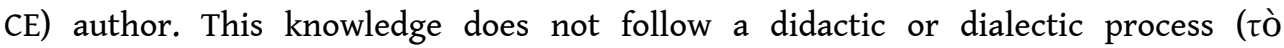

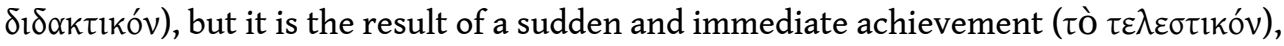

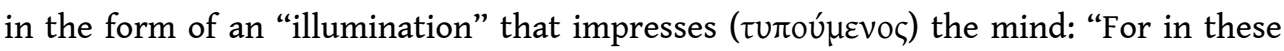
mysteries who is initiated is struck by the visions, but does not receive any teaching". ${ }^{56}$

The evidence of the Greek and Roman periods consistently shows that mysteries were occasional rituals weighted with a heavy emotional dimension that operated on memory. ${ }^{57}$ The rhetor Sopater (fourth century CE) reports his experience at Eleusis in a unique personal testimony: "I came out of the mystery hall feeling like a stranger to

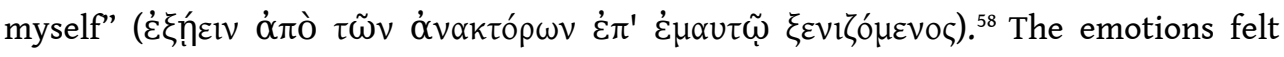
during the initiatory ritual were mostly related to the viewing of specific objects or a divine epiphany as in Eleusis. ${ }^{59}$ The philosophical tradition evokes them as paradoxical experiences that combined terror and light/enlightenment, albeit in a metaphorical way. ${ }^{60}$ Thus images of initiation are analyzed through the lenses of traumatic events, as is the case with the Mithraic frescoes. These specific experiences fostered another consensus among ancient authors: the call for allegorical images in discourses on the initiatory experience. A rhetorical text of the second century CE (falsely attributed to Demetrios of Phaleron) states: "This is why mysteries are revealed in allegories ( $\Delta$ lò

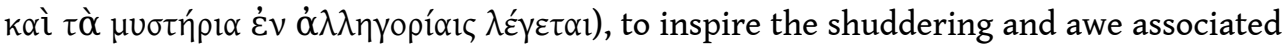

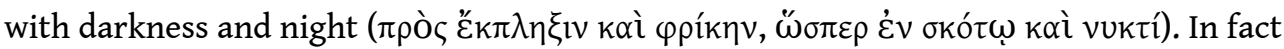

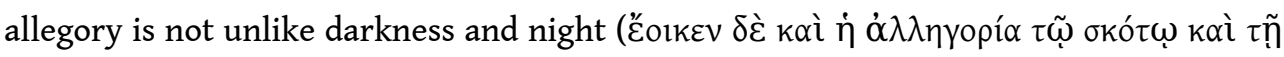
vvkนí)" ${ }^{61} \mathrm{~A}$ century later, Plotinus said that "mysteries and myths concerning the gods

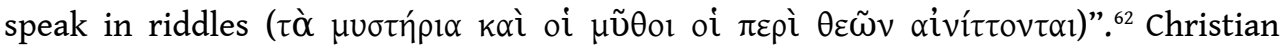
authors shared this approach, albeit with a different agenda. Clement of Alexandria, in his long polemical development on "pagan" mysteries, stressed this emotional dimension as well, and related it to the tragic stories of the gods..$^{63}$ The question of the relationships between myth, ritual, and images is an important one, and it meaningfully interacts with the topic of this collection - all the more acutely in the case of Mithras whose "myth" is reconstructed on the basis of an iconographical analysis. However, one cannot consider that any depiction of the myth conveys a mysteric meaning or attests to mysteric rites, as is for instance surmised by the editors of the mosaic of the House of Dionysos in Sepphoris in Galilee. ${ }^{64}$

The evidence for mystery cults, whether textual or visual, entails a system of signs, just as any language. And yet it matches a specific difficulty, because of the two features I underlined (the interdiction on divulgation and the incommunicability of experience), which deprive the modern observer of data and comparable parallels. Moreover, the investigation becomes more complex when one considers a phenomenon that $\mathrm{F}$. Massa and I have proposed to designate as "mystericization", that is the extensive use of both a lexicon and an imaginaire of "mysteries" that spread in literature and in various fields of knowledge of the Roman period from the end of the first century CE onwards. ${ }^{65}$ Plutarch offers a perfect example of this trend when he presents philosophia as a $\mu \nu \sigma \tau \eta \rho \imath \omega ́ \delta \eta \varsigma ~ \theta \varepsilon o \lambda o \gamma i ́ \alpha$ since it proceeds towards the One through successive steps, each 
one marked by its own distinctive quality. ${ }^{66}$ As a consequence of a hidden reality which could in fact be more metaphorical than ritual - the "mystical silence" ${ }^{67}$ prompts divergent interpretations on the nature of this ritual reality, on its content(s), purposes, and even actual existence for some "mystery cults" (such as the "mysteries" of Egyptian cults). ${ }^{68}$

\section{'Seeing' and 'Viewing': an Eleusinian Model}

The question of seeing and viewing deserves special mention in a discussion of images of initiations in the Mithras cult for it is explicitly painted on frescoes. It is possible to represent what is seen or not - whatever it is - and seeing combines two levels of meaning: it reveals ritual moments when things are shown and viewed or not, and it expresses a passage from a previous state to another one, whatever the latter may be. In the lexicon related to mystery cults, and mirroring the model of the Eleusinian mysteries ("prototypical", in Bremmer's words), terms pertaining to the seeing and the viewing are in the majority - as both the Eleusinian title hiero-phantes and the stage of

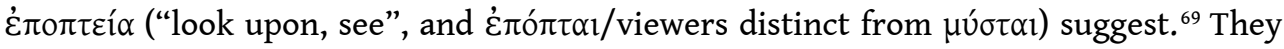
are part of a wide range alluding to things or images shown and seen during the secret experience, like the iहpó (which are both the ceremony and sacred objects) that the

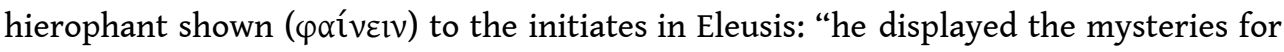

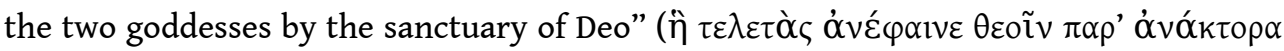
$\Delta \eta \bar{v} \varsigma) .{ }^{70}$ The climax of the initiation ritual was the revelation of the hiera that were carefully kept in the anaktoron during the year. ${ }^{71}$ Among the hiera shown in the Telesterion during the "brilliant nights", there was probably also a revelation of the grains (with the performance of the Hymn?) that everybody knew as Demeter's gift. Varro confirms the pattern for what he calls the Ceres mysteria, probably in the wake of Eleusis: "many things are transmitted in her mysteries (multa in mysteriis eius tradi) which only refer to the discovery of fruits (quae nisi ad frugum inuentionem non pertineant)". ${ }^{72}$ The heresiologist pseudo-Hippolytus is even more explicit when he evokes the epopteia: "The Athenians [...] when they initiated according to the Eleusinian

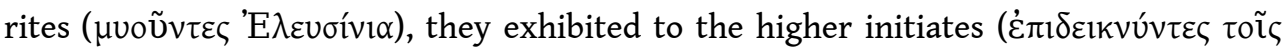

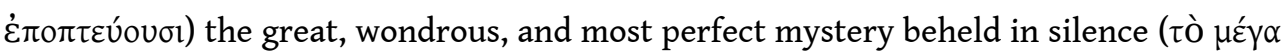

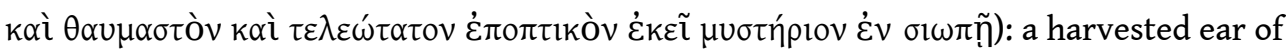

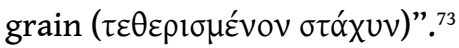

11 Besides the objects that are shown, the most frequent way of expressing the process of initiation in textual evidence is a visual statement: the "light-bringing rites" (ôpүı $\varphi \alpha \varepsilon \sigma i ́ \mu \beta \rho о \tau \alpha)^{74}$ achieve the passage from darkness to lightness (blindness to vision) and

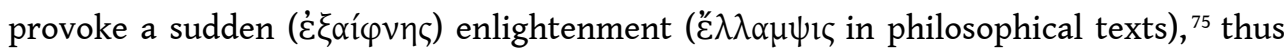
vision(s) that images of mysteries might have tried to express. These revelations through viewing go as far as to be shown eventually in the ritual attire of the Isiac priests or initiates, which would display visually their sacred knowledge according to

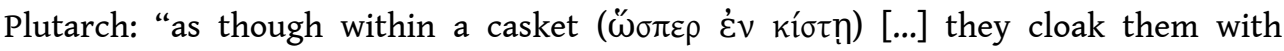
secrecy, thus giving intimations, some dark and shadowy, some clear and bright, of their concepts about the gods, intimations of the same sort as are clearly evidenced in the wearing of the sacred garb." ${ }^{\prime 76}$ These initiated Isiac agents became themselves a kind of cista that was the visual marker of mysteries, ${ }^{77}$ except in the Mithras cult. After reporting the myth of Isis and Osiris, and producing an interpretation of his own, 


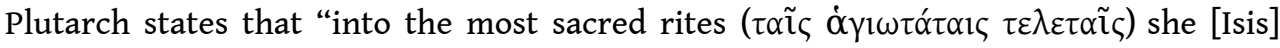

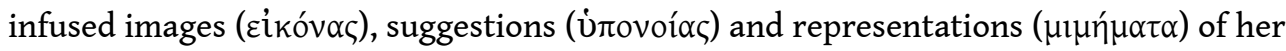

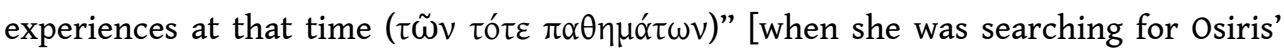
body $].^{78}$ The list of the three forms of visuality is noticeable because it mixes material and mental (imaginative) representations. Similarly the construction of the images induces an intellectual, speculative or imaginative discourse on the lived reality, which is also shaped by the cultural environment of both producers and viewers.

Yet one may wonder why somebody would have visually represented what is forbidden to disclose to "profanes", even the mere topography of the inner sanctuary at Eleusis according to Pausanias: "the uninitiated are of course not permitted to learn that

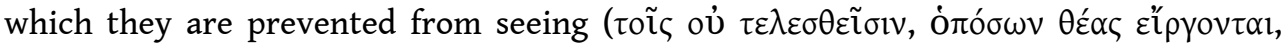

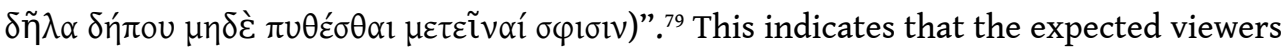
of images of mysteries were insiders (i.e. initiates): the frescoes that will be examined in what follows are indeed inside the spaces of the mithraea opened only to the members of the groups, and consequently their visual language had to talk to this audience. Moreover, the silence ban might have been deemed to have been respected because visual representations (whatever they are, and for any ritual) are not replications or "literal" illustration of realia. Images (just like texts) are visual constructs, which select elements and combine them for conveying messages on various fields: ritual experience, ritual space, group identity, possibly doctrinal assertion. Being signs, chosen for their capacity for analogy, similitude or resemblance, and carrying a whole range of possible values, the elements whose assemblage

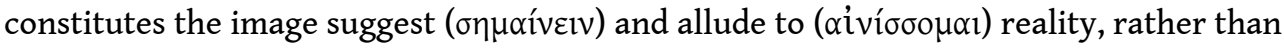
they depict it, as the rituals themselves.$^{80}$ For instance, figures wearing animal masks in Mithraic reliefs (like the corax and leo in that of Konjic) do not imply that the worshippers wore actually masks during the ceremonies, ${ }^{81}$ as regularly envisioned from Cumont onwards on the basis of a passage in a late fourth-century polemical Christian text..$^{82}$ Images carry their own meanings according to their own logic and they can be far removed from the reality of the acts. Displaying a polyvalent semantic system similar to that of texts, ${ }^{83}$ they show what their producers considered both worthy to be shown and available to be viewed. The viewers for their part saw images with their own cultural and imaginative background - as modern viewers also do through their own and their viewing contributed to building the meaning of the image. It is thus important to bear in mind who could see those images.

\section{Mithraic Frescoes as Images of Grouping and Contrasted Agencies}

13 Since we ignore what we are looking for, both because of the specific features of mystery cults and the nature of visual language with its own semiotic rules and metaphorical settings,${ }^{84}$ it is not easy to identify the images that carry representations of initiation scenes, even when testimonies are as numerous as is the case with the Mithras cult. However, insofar as the Mithras cult is a Roman invention, we cannot rely on the visual markers of the Greek "mystery cult" tradition to decipher the Mithraic images, especially the cista of the Eleusinian mysteries, ${ }^{85}$ which later spread over other cults like the mysteries of Isis ${ }^{86}$ and Mater Magna ${ }^{87}$ Torches as "markers" of Cautes and Cautopates (the "torch-bearers") are a significant exception, ${ }^{88}$ though their 
representation bypasses the iconography of mystery cults. Even without these objects, the imaginaire of the mystery cults remains.

Against the backdrop of all these contextualizing settings, I can now focus on the frescoes to which scholars have given a documentary value for reconstructing initiation scenes. These few images might open up access to the climax of the religious experience that is otherwise evoked in texts written by outsiders, whether philosophers or Christian writers. In the 1960s paintings of initiation scenes in two Italian mithraea were found (Santa Prisca on the Aventine in Rome) or properly published (Sta Maria Capua Vetere, discovered in 1924). To be more precise, those of Santa Prisca on the Aventine in Rome represent only processions, with acclamations of the different grades and five leones carrying sacrificial offerings. ${ }^{89}$ Processions are not part of the initiation process itself (they might follow it in form of acclamation of the new initiates), yet they were understood as a subsequent sequence to the initiation of the leones (the first of the high grades, according to R. Gordon) - therefore with the tacit assumption that the initiation was a collective ritual. The point has to be kept in mind as far as the frescoes picture only an individual. The frescoes at Santa Maria Capua Vetere, discovered on the faces of the side-benches in the 1922 excavations by A. Minto and dating to the late Severian period, are more suggestive of an initiatory practice, although they are not depictions. ${ }^{90}$ Two other major discoveries started to build some sort of series: the frescoes of the mithraeum of Caesarea Maritima in Roman Palestine, discovered in the 1970s but published only recently, ${ }^{91}$ and I also add to the discussion an adorned krater (Schlangengefäss) from Mainz (Germany), first published in 1994 by H.G. Horn, who identified on one face (B) a procession alike and on the other (A) three figures read as within an initiation process. ${ }^{92}$

15 All these images were found inside mithraea, in the central meeting room with benches. They were thus intended for the members of the groups and did not break the rule of silence. Yet the intention of the paintings remains unclear: a memorial function, a didactic purpose, or a warning for candidates to initiation? ${ }^{93}$ Answering these questions is challenging as we are still ignorant on the context of initiation: were the members all initiated or on the path to initiation? Was initiation the condition of entering within a group? ${ }^{94}$ Did all the members have a grade? Did all the mithraea over the Empire have the same number of grades (probably not)? Did all the promotions to a new grade have to experience another initiation? ${ }^{95}$ Was the initiation ritual the same for all the grades (thus the eventual trauma would have not been repeated)? Was it a reiteration (thus a lived experience already known) or a progression? Attempts to relate the frescoes to one specific grade have proven inconclusive (see below).

16 I shall not delve at length on the details of the Italian and German images because they already received due attention. ${ }^{96}$ My main concern is to underline the extent to which the reading of these images has contributed to building an interpretative model that lent itself to uncritical acceptance. 
Fig. 1. The Mainz Mithraic Vessel: Side A, an "initiand" (middle) between a Pater (left) and a "mystagogue" (right).
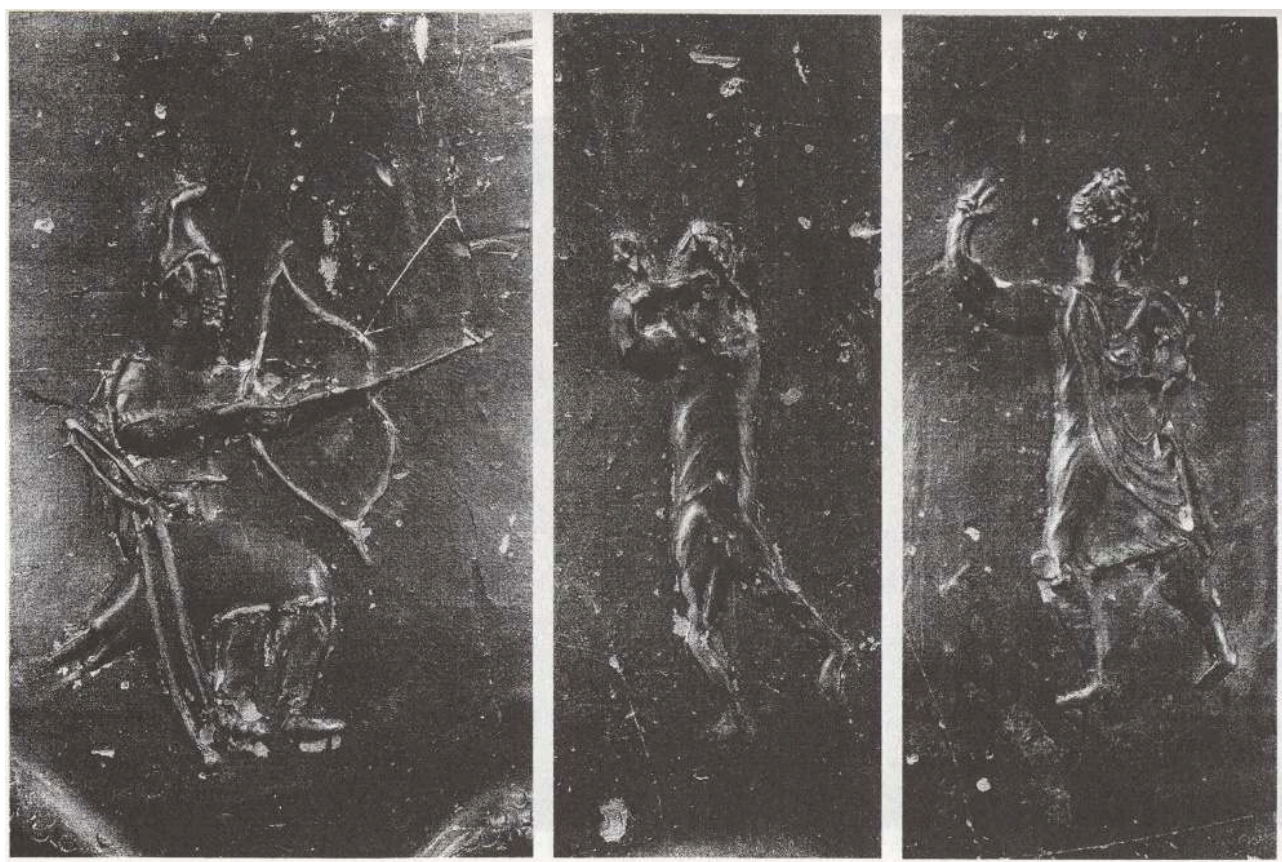

Photo Landesamt für Denkmalpflege Rheinland-Pfalz, Mainz

Fig. 2a. CIMRM 187 fig 57 and 191 fig. 59
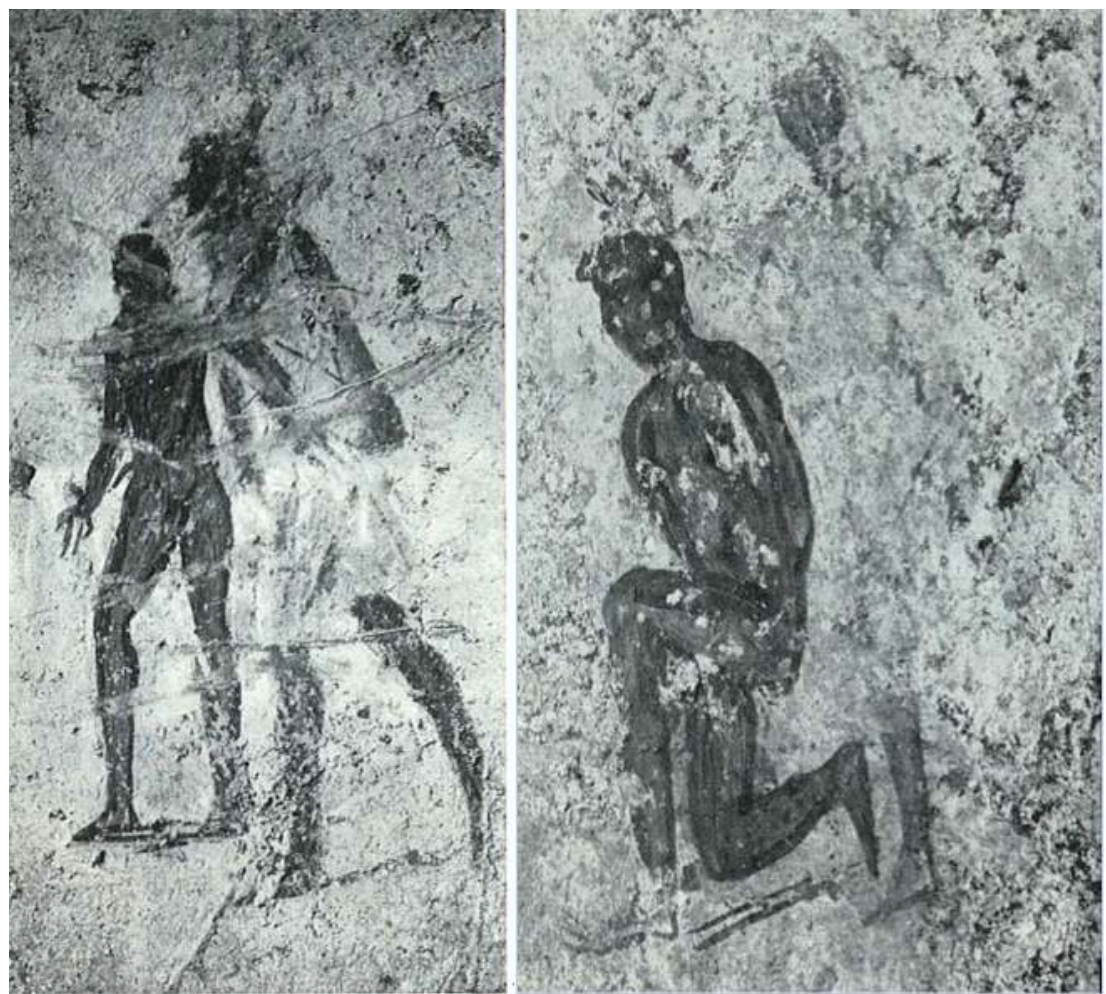

http://www.tertullian.org/rpearse/mithras/display.php?page=cimrm 
Fig. 2b. The Mithraeum at S. Maria Capua Vetere.

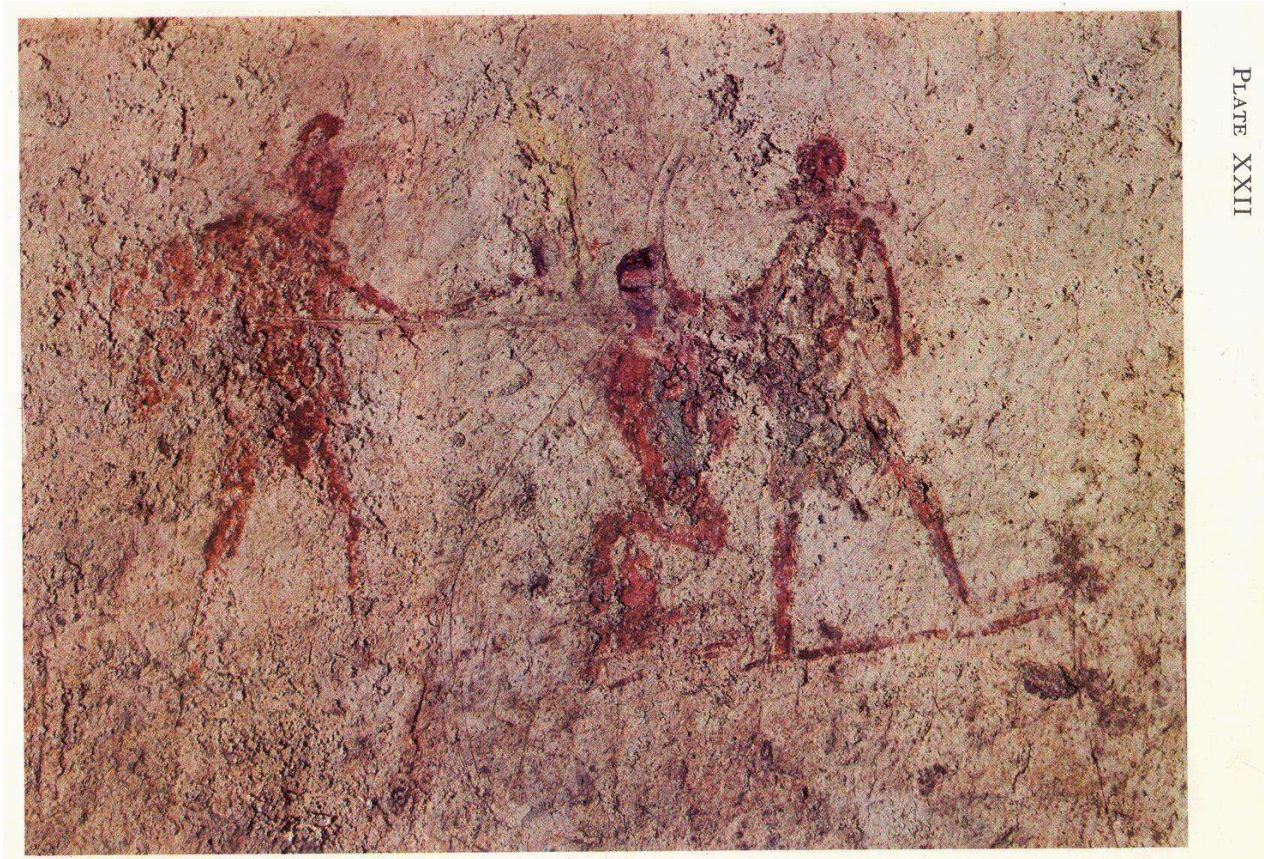

M.J. Vermaseren, Mithriaca I. Leiden, 1971, panel II (W), pl. XXII.

17 Vermaseren's reading of the Capua frescoes (the images which remain the basic reference point in many scholarly discussions) is not straightforward when he uses textual evidence to reconstruct the meaning of images. His conclusion ultimately denies an eventual help from textual narratives, ${ }^{97}$ although he calls on them extensively to interpret some panels. His imaginaire of the experience of initiation - a symbolic death and revival - is modelled by ancient texts related to the Eleusinian "Great Mysteries" and evoking this experience as a progressive path towards happiness through extreme suffering. Vermaseren interpreted the frescoes as actual representations of the successive stages experienced by the neophytes. He called into play Christian texts in the effort to decrypt the scenes, for instance panel V (fig. 2a, right), which he related to Tertullian's On the Crown:

"The well-known passage from Tertullian's de corona concerning the initiation of the miles may be quoted in illustration of the scene at Capua [...] he now relates the ceremony of the crown in greater detail [...] Tertullian does not tell us who offers the crown to the miles [...] This act is compared to martyrdom in which again it is the sword that confers the crown". ${ }^{98}$

Thus, Vermaseren was fully aware of the Church Father's biased reading through the lenses of a polemical, competitive discourse - quasi mimum martyrii, ${ }^{99}$ while he still considered the text as a "comment" on the image, as Cumont did. ${ }^{100} \mathrm{He}$ tries therefore to solve the inconsistencies between the text and the images, with no critical eye on the method itself. He thus interprets the round object above the head of the kneeling figure as a crown (the "only one obvious similarity", M. J. Vermaseren); ${ }^{101}$ that is very doubtful, ${ }^{102}$ and it would be helpful to reexamine the reading with colour filters techniques (much as the frescoes are now badly damaged). Another passage of Tertullian is called for again in order to interpret an object that could be a sword (sub gladio redimit coronam; panel II, fig. 2b) ${ }^{103}$, but "the object might equally be a staff" (Vermaseren). Vermaseren also had to confront the wider differences between the 
images and the narrative of the text, and he bypassed them in retaining the initiatory pattern, albeit for a neophyte and not for a miles, according to Tertullian's text. ${ }^{104}$

When one starts from the painted images, without a positivistic illusion of "photographs" of lived ceremonies, the major feature is the emphasis put on figures who express different agencies through contrasting modes of behaviour, like in groups with a strong hierarchy: a figure (the initiand) is acted ${ }^{105}$ (nude, lying, ${ }^{106}$ kneeling, beardless as a youth, hands bound, ${ }^{107}$ blindfolded, pushed) - what texts about the Eleusinian Mysteries describe as "fear and anguish", $\dot{\alpha} \gamma \omega v i \alpha^{\alpha} .{ }^{108}$ Yet images do not represent the second/final step expressed in the texts, the "joy and happiness", $\dot{\eta} \delta o v \eta \dot{\eta}$, that is the achievement of the initiation: "But after this, a marvelous light appears". ${ }^{109}$ The most noticeable visual features are attitudes and gestures construing opposite couples $^{110}$ that can express two statuses within the group - possibly the "change of mind" of W. Burkert, that is the $\mu \varepsilon \tau$ óvola resulting from a peculiar experience: the naked candidate to initiation versus already initiated ritual agents who are vested; the candidate kneeling and lying versus ritual agents standing; the candidate powerless facing armed figures (in the Mainz vessel alike); the candidate pushed or led by someone standing behind him; the candidate with eyes covered or discovered in order to evoke blindness before vision as the standing figures - possibly "illumination" as texts say. The unique attribute of a grade that is painted (moulded on the krater) is the Phrygian cap of the Pater and his Persian dress - a "stylistic gesture" for J. Elsner ${ }^{111}$ on the vase (fig. 1 on the left; fig. 2b): definitely the only grade that is attested in all the mithraea. ${ }^{12}$ The krater of Mainz was read as a promotion or initiatory scene along the same lines. ${ }^{113}$ It does indeed display some formal similarities, although the visual choices are different for representing the relationship between the three figures (one seated and two standing; one nude and two with garments). R. Beck proposed to combine two levels of reading, a human/ritual one related to an initiation experience, and a mythical one "mimicking the mythic archery of Mithras". ${ }^{114}$ Yet the gesture would not be totally over-realistic in the strategic position of the castrum of Mainz/ Mogontiacum in the Agri Decumates, where two (then one) legion(s) were stationed, and where the picture of an archer could easily be related to the military context of the local community.

The submission of the central figure (the "initiand") is evoked through the nudity and the "archery of the Father" (R. Beck, side A, fig. 1), a frightening episode lived by the initiand, yet far from "the shuddering and awe associated with darkness and night" in pseudo-Demetrios' terms. ${ }^{115}$ The initiand threatened to death by an enthroned Father has behind him another figure (fig. 1 on the right) whose gestures - his head looking upwards, his mouth opened, and his right arm raised - evoke someone speaking. ${ }^{116}$ One might envision some kind of ritual trial in front of the god/Pater. Scholars call him "mystagogue", fitting with a ritual function, but who does not match an identified grade. The visual "programme" of face A is not especially terrifying, because the archery that can credibily be seen in a mythical and metaphorical way (i.e. with Mithras as an archer), unless it is paralleled with the interpretative model developed from the reading of the Capua frescoes. However, considering that Mithraic groups were atomized communities, ${ }^{117}$ modern studies miss solid ground to establish common initiatory patterns across the empire as a whole. Doing so with such few attestations relies on a petitio principii that puts a model, the Eleusinian one, as relevant for any cult labelled as "mystery cult" by the historiography. Yet recent studies demonstrate that 
the category of "mystery cults" per se is not at all obvious: the evidence is both too scarce and too diverse. ${ }^{118}$ The problem is enhanced by the so-called mysteries of Mithras: they were invented in Roman milieus with no hints to Eleusinian themes or rituals, as far as we know.

In 2017 the poorly preserved frescoes of the mithraeum of Caesarea Maritima in SyriaPalaestina, painted on the wall of the meeting room, were published. ${ }^{119}$ The archaeologists made tremendous efforts to read them, with the help of new technologies (fig. 3). This set of material offers a good case study to push further the methodological reflections linked to the reading of evidence through the lenses of a model.

Fig. 3. R. J. Bull et al., The Mithraeum at Caesarea Maritima, Boston.

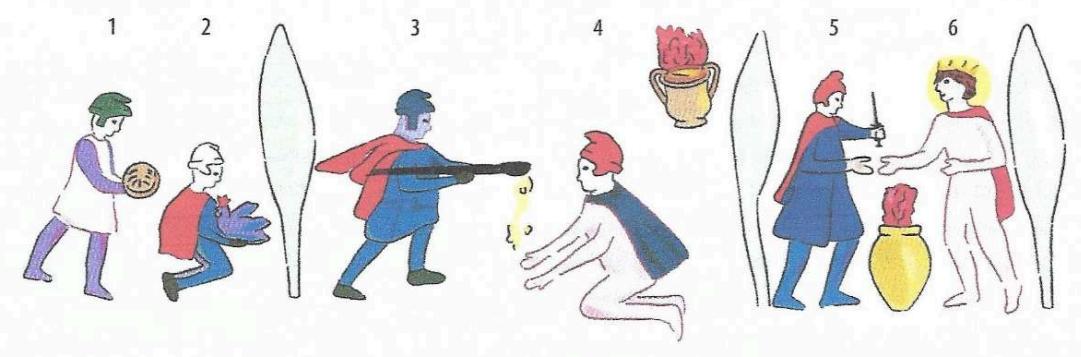

Fig. 42 Color reconstruction of surviving fresco panels, with described individuals numbered (Sapir Head).

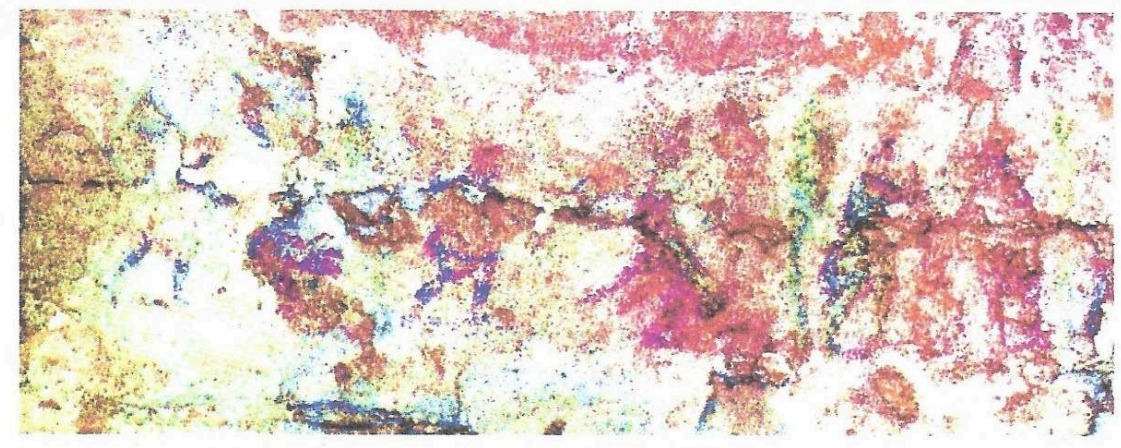

FIG. 43 Color saturated and tone balanced image of fresco on south wall (Bobeck).

ASOR, Archeological Reports 25, 2017, fig. 42-43.

A few years before the publication of the final report, in 2011, E. M. Moorman, after R. Gordon, had already proposed a reading of the scenes as the narrative of the god as a guiding principle - possibly in the wake of the Hawarte mithraeum: "The three scenes having Mithras' life on the side walls have Mithras kneeling in front of Sol, Mithras shaking hands with Sol and Mithras riding on a bull to Oceanus or Saturnus. The images are framed by trees which look like cypresses." ${ }^{120}$ In their 2017 final report, the archaeologists modeled their reconstruction of the spelaeum upon an astronomical reading, ${ }^{121}$ and the deciphering of the frescoes upon the Capuan interpretations and a strong set of textual evidence. Yet we already noticed how far interpretations based on a literary corpus can be biased upon the texts that are invoked for. Moreover, this method postulates that it existed a "standardized iconographic visual program" spread in all mithraea - an assertion that presupposes a prescriptive authority like in a centralized "Church". The fact that the tauroctony reliefs display an amazing uniformity besides details ${ }^{122}$ is still a question, because we know that Mithraic 
communities were atomized groups, within which the religio-cultural envisioning of the Father was surely important. ${ }^{123}$ The two contemporary Syrian mithraea at Sidon and Hawarte near Apamea (second half of the fourth century), with their two different visual inspiration (Greek in Sidon and Persian in Hawarte), are convincing on this count. ${ }^{124}$ Concerning Caesarea further south, the authors identify the paintings as displaying a chronological narrative of the initiation of the leones, the grade pictured in Sta Prisca. ${ }^{125}$ They read the three sequences (fig. 3) through the initiatory model of an extreme, near-death experience, provoking the transformation of the initiate, although the drawing they provide to the modern reader (fig. 3) does not convey such a terrifying atmosphere.

The first scene on the left (panel A) depicts a procession, with two figures, one standing and one kneeling, bringing offerings (a bread loaf and a cock) for the ritual meal. ${ }^{126}$ It can remind other procession scenes, e.g. at Santa Prisca in Rome when the Lions are acclaimed. Yet it is not strictly speaking part of the initiation ritual. Ritual meals were a regular meeting occasion for Mithraic groups ${ }^{127}$ (in happiness, as a Roman Pater reminds us), ${ }^{128}$ and we noted that on the Aventine there is no argument for deciding between the end of an "initiatory ritual" and just an 'administrative' promotion to a higher grade. Moreover, the parallel of the mystery festival at Andania in Messenia, which is known in detail because its ritual regulations were engraved, invites to distinguish the different stages. ${ }^{129}$ The second panel (B) ${ }^{130}$ encapsulates the main interpretative issues. It pictures a man standing, vested with oriental pants and a short cloak, who delivers something to a man in front of him with a kind of stick, possibly a torch. This second figure is nude, except a short cloak on his shoulders; he is kneeling and receives what is given in his hands. One can imagine that nudity, the kneeling position and the stick prompted the editors to model their reading and method on that of Vermaseren for the Capua mithraeum, although the context of the scene looks very different. The editors search for texts giving an "illustration" to the images. But, although the two texts which could enlighten the images refer to the grade of Lion (the grade acclaimed at Sta Prisca), the authors cannot decide between Tertullian in an antignostic treatise which points to a frightening "fire-test", ${ }^{131}$ and the Neoplatonic Porphyry in On the Cave of the Nymphs (thus after the frescoes were painted) who evokes a peaceful purificatory rite with honey: "When they pour honey instead of water on the

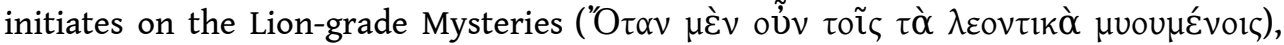

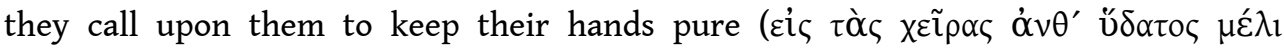
ví $\psi \alpha \sigma \theta \alpha 1 \dot{\varepsilon} \gamma \chi \varepsilon^{\prime}(\omega \sigma)$ )". ${ }^{132}$ The crater painted in the field (up on right) might give precedence to Porphyry ${ }^{133}$ - if one expects images to be visual expressions of discourses - but it is well known that this text displays the perfect achievement of an allegorical reading, غ่v $\sigma u \mu \beta{ }^{\prime} \lambda \omega::^{134}$ the experience displayed visually has no traumatic features. Finally, the last panel (C, fig. 3 on the right) shows the dexiosis between Sol in divine nudity and Mithras, a motive that is frequently depicted on reliefs as well; we come here to a mythic level. The editors dramatize it as a "blood-pact", and call for another text then, belonging to another cultural context (praised by Cumont), an Avestic feature of Mïra as god of oath: "The inclusion of this scene among the other images indicates that the blood pact was part of this specific ceremony, a conclusion to the rites sealing the transition of the mystes with a sacred oath to the god/cult father". ${ }^{135}$ Whatever could be this enigmatic "transition of the mystes" (Burkert's "change of 
mind"?), again, the atmosphere does not smell the near-death experience model that the editors follow.

When looking for images first, rather than displaying a chronological sequence of initiation (as archaeologists advocate), this whole set seems to be drawing through visual codes the three different ways through which a religious group might give an image both of itself and to itself: a collective ritual one with the procession (A), the initiation with a transmission (tradere in Latin) without necessarily having a special terrifying ambiance (B), and a mythological narrative on the gods sponsoring the group, through the riddle of the dexiosis (C). The three features here identified fit with the main outlines I started from. Moreover, the only point of consensus in all testimonies (either literary or archaeological, pagan or Christian, insiders or outsiders) is the collective meeting, generally accompanied by a meal - thus within a reserved circle, the reason why Christian polemicists focused on these rituals. ${ }^{136}$ It is worth noting here that this was the explicit meaning of $\mu \nu \sigma \tau$ ńprov in the letters sent by the priests of Zeus in Carian Stratonicea in order to invite the neighbouring cities to the $\delta \varepsilon \tilde{I} \pi v o v$ in the presence of the god. ${ }^{137}$

This attempt to cope with the question of images of initiation in the Mithras cult demonstrates, in my view, that these images are difficult to identify because they cannot be read through one-dimensional models or uncontextualized texts. For instance, on the basis of both the starred ceiling of two mithraea (Santa Maria Capua Vetere and Dura Europos) and an astronomical reading, the scholarly consensus reconstructs the vaults of mithraea as depicting a dark blue sky studded with stars; and yet many other sanctuaries disprove the supposed 'rule', like the paintings of the Güglingen mithraeum II, which display a "profane Gestaltung" with "ein geometrisches Muster" (coffered ceiling type). ${ }^{138}$

Moreover, as a general observation, it proves hazardous to interpret images on the basis of discourses that mobilize their own significant elements according to their own argumentative perspectives. Even after the "visual turn", the prevailing method for deciphering (supposed) images of Mithraic initiation consists of calling for texts. Notwithstanding the fact that each mithraeum had probably its own cultural and identity references (for instance, between a military context on the limes and an urban one in Rome), these texts are of two kinds: either they are philosophical texts, which speak in riddles (as authors say) and are of late date for some, compared to that of the creation of the iconographic programs; or they are Christian texts, with apologetic and polemical strategies, for the Fathers considered that mystery cults were the major competitor of Christianity that had its own mysterion - or at least they chose to present them in that way. ${ }^{139}$ Thus mysteries were imposture for them. We ignore how Christian authors were informed about pagan mysteries, as far as there was a silence ban. Even if they got first-hand information, it is clear that they biased the picture because of their ideological goals, as we noticed with the chapter of Tertullian's De Corona ${ }^{140}$ It is thus more prudent to avoid starting with a literary model and to read images according to their own codes. The picture that the painted images of three mithraea convey some similarities. Yet they do not all fit (except for the Capua ensemble) with the model of fright, which is also based on a literary blueprint, notably the philosophico-Eleusinian tradition, and they do not display any hint of the enjoyable moment that is also part of the model. Moreover, their very low numbers, combined with their differences, makes 
it impossible to establish a general pattern. The initiation rituals in mithraea remain a mystery.

\section{BIBLIOGRAPHY}

ADRYCH 2021: P. Adrych, «The Seven Grades of Mithraism; or How to Build a Religion», in N. Belayche and F. Massa (eds.), Mystery Cults in Visual Representation in Graeco-Roman Antiquity, Leiden-Boston 2021, 103-122.

ADRYCH, BRACEY, DALGLish, LenK, Wood 2017: Ph. Adrych, R. Bracey, D. Dalglish, S. Lenk and R. Wood, Images of Mithra. Visual Conversations in Art and Archaeology I, Oxford 2017.

AKçAY 2019: K. N. Akçay, Porphyry's On the Cave of the Nymphs in its Intellectual Context, LeidenBoston 2019.

ALVAR 2008: J. Alvar, Romanising Oriental Gods: Myth, Salvation and Ethics in the Cults of Cybele, Isis and Mithras, Leiden-Boston 2008.

BARATTE 2001: F. Baratte, «Le mithreum de Sidon: certitudes et questions», Topoi 11 (2001), 205-227.

BECK 1998: R. Beck, «The Mysteries of Mithras: A New Account of their Genesis», JRS 88 (1998), 115-128.

BECK 2000: R. Beck, «Myth, Doctrine, and Initiation in the Mysteries of Mithras: New Evidence from a Cult Vessel», Journal of Roman Studies 90 (2000), 145-80.

BECK 2006: R. Beck, The Religion of the Mithras Cult in the Roman Empire. Mysteries of the Unconquered Sun, Oxford 2006.

BECK 2008: R. Beck, «Myth, Doctrine, and Initiation in the Mysteries of Mithras», in Alvar, Romanising Oriental Gods, 154-157.

BELAYCHE 2006: N. Belayche, «Note sur l'imagerie des divinités 'orientales' dans le Proche-Orient romain», in C. Bonnet, J. Rüpke and P. Scarpi (eds.), Religions orientales - culti misterici. Neuen Perspektiven - nouvelles perspectives - prospettive nuove, Stuttgart 2006, 123-133.

BELAYCHE 2008: N. Belayche, «Du texte à l'image : les reliefs sur les stèles 'de confession' d'Anatolie», in S. Estienne et al. (eds.), Images et Religion, Naples 2008, 181-194.

BELAYCHE 2009: N. Belayche, «La polémique pagano-chrétienne autour du repas rituel (II ${ }^{\mathrm{e}}-\mathrm{IV}^{\mathrm{e}}$ siècles) : un conflit d'identités'», in N. Bériou et al. (eds.), Pratiques de l'eucharistie dans les églises d'Orient (Antiquité et Moyen-Âge), Paris 2009, I, 521-537.

BELAYCHE 2016: N. Belayche, «Les hiérophantes marqueurs des « mystères » ? Le cas de l'Artémis éphésienne», Mètis n.s. 14 (2016), 49-74.

BELAYCHE 2017: N. Belayche, «Nomen ostendit (Macrobe). Rites et images, les supports des noms de Janus», in N. Belayche and Y. Lehmann (eds.), Religions de Rome. Dans le sillage de Robert Schilling, Turnhout 2017, 67-83. 
BELAYCHE 2021a: N. Belayche, «Rituels en images - Images de rituels: quelques réflexions sur textes et images», in A.-F. Jaccottet (ed.), Rituels en images - Images de rituels. Iconographie, histoire des religions, archéologie, Berne 2021, 247-254.

BELAYCHE 2021b: N. Belayche, «Percer la loi du silence? Les "nuits illuminantes" à Éleusis au II siècle ", in Belayche, Massa and Hoffmann (eds.), Les Mystères au II ${ }^{e}$ siècle de notre ère, 25-53.

BELAYCHE (forthcoming): N. Belayche, «Les dévots latinophones de Mithra disaient-ils leurs mystères, et si oui comment?», in F. Massa and D. Nelis (eds.), Mystery Cults in Latin Texts, Mnemosyne forthcoming.

BELAYCHE, MASSA 2016a: N. Belayche and F. Massa (eds.), Les « mystères » : questionner une catégorie, Mètis n.s. 14 (2016), 7-132.

BELAYCHE, MASSA 2016b: N. Belayche and F. Massa, « Quelques balises introductives : lexique et historiographie ", Mètis n.s. 14 (2016), 7-19.

BELAYCHE, MASSA 2021a: N. Belayche and F. Massa (eds.), Mystery Cults in Visual Representation in Graeco-Roman Antiquity, Leiden-Boston 2021.

BELAYCHE, MASSA 2021b: N. Belayche and F. Massa, «Mystery Cults and Visual Language in GraecoRoman Antiquity: An Introduction», in N. Belayche and F. Massa (eds.), Mystery Cults in Visual Representation, Leiden 2021, 1-37.

Belayche, MASSA, HoffMAnN 2021: N. Belayche, F. Massa and Ph. Hoffmann (eds.), Les mystères au II ${ }^{e}$ siècle de notre ère: un tournant, Turnhout 2021.

BÉRARD 2018: C. Bérard, Embarquement pour l'image. Une école du regard, Basle 2018.

BÉRARD et al. 1984: La Cité des images. Religion et société en Grèce antique, Lausanne-Paris, 1984 (English transl. A City of Images. Iconography and Society in Ancient Greece, Princeton 1989).

BÉRARD, BRON, POMARI 1987: F. Bérard, Chr. Bron and A. Pomari (eds.), Images et société en Grèce ancienne : L'iconographie comme méthode d'analyse, Lausanne 1987.

BERNABÉ 2016: A. Bernabé, “Aristotle and the Mysteries,” in Martin-Velasco, Garcia Blanco (eds.), Greek Philosophy and Mystery Cults, 27-42.

BIANCHI 1965: U. Bianchi, "Initiation, mystère, gnose," in C. J. Bleeker (ed.), Initiation, Contributions to the Theme of the Study-Conference of the I.A.H.R., Strasbourg, September $17^{\text {th }}$ to $22^{\text {nd }} 1964$, Leiden 1965, 154-171.

BIANCHI, VERMASEREN 1982: U. Bianchi and M. J. Vermaseren (eds.), La soteriologia dei culti orientali nell'Impero romano. Colloquio internazionale Roma 1979, Leiden 1982.

BlAKELY 2009: S. Blakely (ed.), "Proceedings of the Conference on the Mysteries," Electronic Antiquity 12, 1 (2009), http://scholar.lib.vt.edu/ejournals/ElAnt/V12N1/, last access 23.01.21.

BonNET 1997: C. Bonnet, “Franz Cumont et l'exégèse iconographique”, Hiéros 2 (1997), 21-30.

Bonnet, PirenNe-Delforge, Praet 2009: C. Bonnet, V. Pirenne-Delforge and D. Praet (eds.), Les religions orientales dans le monde grec et romain: cent ans après Cumont (1906-2006). Bilan historique et historiographique, Brussels-Rome 2009.

BONNET, RÜPKE, SCARPI 2006: C. Bonnet, J. Rüpke, P. Scarpi (eds.), Religions orientales - culti misterici, Stuttgart 2006.

BOWDEN 2010: H. Bowden, Mystery Cults of the Ancient World, Princeton 2010. 
BRÄUNLEIN 2009: P. J. Bräunlein, “Ikonische Repräsentation von Religion”, in H. G. Kippenberg, J. Rüpke and K. von Stuckrad (eds.), Europäische Religionsgeschichte, Göttingen 2009, 771-810. BREMMER 2014: J. N. Bremmer, Initiation into the Mysteries in Ancient World, Leiden-Boston 2014. Bull et al. 2017: R. J. Bull, J. Derose Evans, A. L. Ratzlaff, A. H. Bobeck, R. S. Fritzius, The Mithraeum at Caesarea Maritima, Boston 2017.

BURKERT 1997: W. Burkert, Ancient Mystery Cults, Cambridge (MA)-London 1987.

BURRELL 1993: B. Burrell, «Two Inscribed Columns from Caesarea Maritima», ZPE 99 (1993), 287-295.

CAMPBELL 1968: L. A. Campbell, Mithraic Iconography and Ideology, Leiden 1968.

CHALUPA 2008: A. Chalupa, «Seven Mithraic Grades: An Initiatory or Priestly Hierarchy?», Religio 16 (2008), 177-201.

Clauss 2001: M. Clauss, The Roman Cult of Mithras. The god and his mysteries, New York 2001 (first German ed. 1990).

CLINTON 2003: K. Clinton, «Stages of Initiation in the Eleusinian and Samothracian Mysteries», in Cosmopoulos (ed.), Greek Mysteries, 50-78.

Cosmopoulos 2003: M. B. Cosmopoulos (ed.), Greek Mysteries. The Archaeology and Ritual of Ancient Greek Secret Cults, London-New York 2003.

CROISSANT 1932: J. Croissant, Aristote et les mystères, Liège-Paris 1932.

CUMONT 1899: F. Cumont, Textes et monuments figurés relatifs aux mystères de Mithra, II, Brussels 1899.

Cumont 1913 [2013]: F. Cumont, Les Mystères de Mithra, Brussels 1913, N. Belayche and A. Mastrocinque (eds.), Bibliotheca Cumontiana, Scripta Maiora III, Turin 2013 [1913].

Cumont $1927^{4}$ [2006]: F. Cumont, Les Religions orientales dans le paganisme romain, C. Bonnet and Fr. Van Haeperen (eds.), Bibliotheca Cumontiana, Scripta maiora I, Turin 2006 [1927 $\left.{ }^{4}\right]$.

Cumont 1975: F. Cumont, «The Dura Mithreum», in J. Hinnells (ed.), Mithraic Studies, First International Congress, I, Manchester 1975, 194-203.

ELSNER 2003: J. Elsner, «Archaeologies and Agendas: Reflections on Late Ancient Jewish Art and Early Christian Art», Journal of Roman Studies 93 (2003), 114-128.

ELSNER 2007: J. Elsner, Roman Eyes. Visuality and Subjectivity in Art and Text, Princeton-Oxford 2007. Estienne, Huet, LisSarRague, Prost 2014: S. Estienne et al. (eds.), Figures de dieux. Construire le divin en images, Rennes 2014.

GAWLIKOWSKI 2007: M. Gawlikowski, «The mithraeum at Hawarte and its Paintings», Journal of Roman Archaeology 20 (2007), 337-361.

GAWLINSKI 2012: L. Gawlinski, The Sacred Law of Andania. A New Text with Commentary, Berlin-Boston 2012.

GORDON 1996: R. Gordon, Image and Value in the Graeco-Roman World. Studies in Mithraism and Religious Art, Aldershot 1996.

GoRDON 2001: R. Gordon, «Trajets de Mithra en Syrie romaine», Topoi 11 (2001), 77-136.

GoRDon 2009: R. Gordon, «The Mithraic Body: The Example of the Capua Mithraeum», in G. Casadio and P. A. Johnston (eds.), Mystic Cults in Magna Grecia, Austin 2009, 290-313. 
GORDON 2013: R. Gordon, «The miles-frame in the Mitreo di Felicissimo and the Practicalities of Sacrifice», Religio: revue pro religionistiku, 21 (2013), 33-38.

GORDON 2017: R. Gordon, «From East to West: Staging Religious Experience in the Mithraic Temple», in S. Nagel, J. F. Quack and C. Witschel (eds.) Entangled Worlds: Religious Confluences between East and West in the Roman Empire. The Cult of Isis, Mithras, and Jupiter Dolichenus, Tübingen 2017, 413-442.

GORDON 2019: R. Gordon, «The Cult of Mithras in Late Antiquity», Review of D. Walsh, The Cult of Mithras in Late Antiquity: Development, Decline and Demise ca. A. D. 270-430, ARYS 17 (2019), 461-475. GRAF 2003: F. Graf, «Initiation. A Concept with a Troubled History», in D. B. Dodd and C. A. Faraone (eds.), Initiation in Ancient Greek Rituals and Narratives. New Critical Perspectives, London 2003, 3-24.

HAMILTON 2009: R. Hamilton, «Basket Case: Altars, Animals and Baskets on Classic Attic Votive Reliefs», in J. T. Jensen, G. Hinge, P. Schultz and B. Wickkiser (eds.), Aspects of Ancient Greek Cult. Context, Ritual and Iconography, Aarhus 2009, 29-53.

HENSEN 2013: A. Hensen, Mithras. Der Mysterienkult an Limes, Rhein und Donau, Darmstadt 2013.

HöLSCHER 2004: T. Hölscher, The Language of Images in Roman art, Cambridge 2004.

HÖLSCHER 2018: T. Hölscher, Visual Power in Ancient Greece and Rome. Between Art and Social Reality, Oakland, 2018.

HULD-ZETSCHE 2008: I. Huld-Zetsche, Der Mithraskult in Mainz und das Mithräum am Ballplatz, Mainz, 2008.

JACCOTTET 2021: A.-F. Jaccottet, «The Liknon and the Bundle: Does the Ritual 'Initiatory' Object Make the Mystery?», in Belayche and Massa (eds.), Mystery Cults in Visual Representation in Graeco-Roman Antiquity, 173-193.

KERÉNYI 1967: K. Kerényi, Eleusis: An Archetypal Image of Mother and Daughter, London 1967.

KLENNER 2019: I. Klenner, Archäologie des Mithraskultes. Architektur und Kultpraxis am Beispiel der Tempel von Güglingen, Kr. Heilbronn, PhD Hamburg 2019 [published I. Siemers-Klenner, same title, Wiesbaden 2020 (non vidi)].

LAMBERTON 1986: R. Lamberton, Homer the Theologian: Neoplatonist Allegorical Reading and the Growth of the Epic Tradition, Berkeley-Los Angeles-London 1986.

LAUMONIER 1958: A. Laumonier, Les Cultes indigènes en Carie, Paris 1958.

MAAR, BURDA 2004: C. Maar and H. Burda (eds.), Iconic Turn. Die neue Macht der Bilder, Cologne 2004.

MARTIN 2006: L. H. Martin, «Cognitive Science, Ritual, and the Hellenistic Mystery Religions», Religion and Theology 13 (2006), 383-395.

MARTIN 2015: L. H. Martin, The Mind of Mithraists: Historical and Cognitive Studies in the Roman Cult of Mithras, London-New York 2015.

Martin-Velasco, Garcia Blanco 2016: M. J. Martin-Velasco and M. J. Garcia Blanco, Greek Philosophy and Mystery Cults, Cambridge 2016.

MASSA 2013: F. Massa, «Écrire pour Dionysos: la présence de textes écrits dans les rituels dionysiaques», RHR 230 (2013), 209-232.

MASSA 2016: F. Massa, «La Notion de 'mystères' au II ${ }^{\mathrm{e}}$ siècle de notre ère: regards païens et Christian turn», Mètis n.s. 14 (2016), 109-132. 
MASSA 2017: F. Massa, «Luci e misteri a Costantinopoli. Concorrenze religiose nell'orazione XXXIX di Gregorio di Nazianzo », Humanitas 75 (2017), 779-790.

MASSA 2018: F. Massa, «Le Mythe fait-il le mystère? Interprétations chrétiennes des mystères égyptiens (II ${ }^{\mathrm{e}}-\mathrm{IV}^{\mathrm{e}}$ siècles) », RHR 235 (2018), 701-722.

MASTROCINQUE 2017: A. Mastrocinque, The Mysteries of Mithras. A Different Account, Tübingen 2017.

MiNTo 1924: A. Minto, «S. Maria di Capua Vetere. Scoperta di una cripta mitriaca», Notizie degli scavi 21 (1924), 353-375.

MonTiglio 2000: S. Montiglio, Silence in the Land of the Logos, Princeton 2000.

MooRmanN 2011: E. M. Moormann, Divine Interiors. Mural Paintings in Greek and Roman Sanctuaries, Amsterdam 2011.

MотTE 1986: A. Motte, «Silence et secret dans les mystères d'Eleusis», in J. Ries and H. Limet (ed.), Les rites d'initiation, Louvain-la-Neuve 1986, 317-334.

MYLonAS 1961: G. Mylonas, Eleusis and the Eleusinian Mysteries, Princeton 1961.

MYLONOPOUlOS 2010: J. Mylonopoulos (ed.), Divine Images and Human Imaginations in Ancient Greece and Rome, Leiden-Boston 2010.

NiLSson 1953: M. P. Nilsson, «The Bacchic Mysteries of the Roman Age», Harvard Theological Review 46 (1953), 175-202.

PANAGiotidou, BeCK 2017: O. Panagiotidou and R. Beck, The Roman Mithras Cult: A Cognitive Approach, Oxford 2017.

Petridou 2013: G. Petridou, «'Blessed is He, Who Has Seen': The Power of Ritual Viewing and Ritual Framing in Eleusis», Helios 40 (2013), 309-341.

Philonenko, Lehmann, Pernot 2017: M. Philonenko, Y. Lehmann and L. Pernot (eds.), Les Mystères : nouvelles perspectives. Entretiens de Strasbourg, Turnhout 2017.

RENAUT 2007: L. Renaut, «Les initiés aux mystères de Mithra étaient-ils marqués au front ? Pour une relecture de Tertullien, De praescr. 40, 4», Mediterranea 4, 171-190.

ROSKAM 2001: G. Roskam, «And a great silence filled the temple...: Plutarch on the connections between mystery cults and philosophy», in A. Pérez Jiménez and F. Casadesús Bordoy (eds.), Estudios sobre Plutarco: misticismo y religiones mistéricas en la obra de Plutarco, Madrid 2001, 221-232.

SABBATUCCI 1965: D. Sabbatucci, Saggio sul misticismo greco, Rome 1965.

SAURON 1998: G. Sauron, La grande fresque de la Villa des Mystères à Pompéi. Mémoires d'une dévote de Dionysos, Paris 1998.

SFAMENI GASPARRO 2003: G. Sfameni Gasparro, Misteri e teologie. Per la storia dei culti mistici e misterici nel mondo antico, Cosenza 2003.

SIEMERS-KLENNER 2020: see KLENNER 2019.

SIMMEL 1950: G. Simmel, «The Secret and the Secret Society», in K. H. Wolff (ed.), The Sociology of Georg Simmel, New York 1950, 305-376.

STIEGLER 2008: B. Stiegler, «'Iconic Turn’ et réflexion sociétale», Trivium 1 (2008), on line: http:// trivium.revues.org/308, last accessed 23.01.21.

TALGAM, WeISS 2004: R. Talgam and Z. Weiss, The Mosaics of the House of Dionysus at Sepphoris, Jerusalem 2004. 
TURCAN 1975: R. Turcan, Mithras Platonicus. Recherches sur l'hellénisation philosophique de Mithra, Leiden 1975.

TURCAN 1993: R. Turcan, Mithra et le mithriacisme, Paris 1993.

Ustinova 2017: Y. Ustinova, Divine Mania: Alteration of Consciousness in Ancient Greece, Oxford 2017.

VAN HAEPEREN 2021: F. Van Haeperen, «The Cista, a hallmark of Mater Magna's mysteries in the Roman world», in Belayche and Massa (eds.), Mystery Cults in Visual Representation in Graeco-Roman Antiquity, 194-217.

VAN NUfFeLEN 2007: P. Van Nuffelen, «Words of Truth. Mystical Silence as a Philosophical and Rhetorical Tool in Plutarch», Hermatena 182 (2007), 9-39.

VAN Nuffelen 2011: P. Van Nuffelen, Rethinking the Gods. Philosophical Readings of Religion in the PostHellenistic Period, Cambridge-New York 2011.

VeRMASEREN 1971: M. J. Vermaseren, Mithriaca I. The Mithraeum at S. Maria Capua Vetere, Leiden, 1971.

VeRMASEREN, VAN ESSEN 1965: M. J. Vermaseren and C.C. Van Essen, The Excavations in the Mithraeum of the Church of Santa Prisca in Rome, Leiden 1965.

VEYMIERS 2021: R. Veymiers, «Les Mystères isiaques et leurs expressions figurées. Des exégèses modernes aux allusions antiques», in Belayche and Massa (eds.), Mystery Cults in Visual Representation in Graeco-Roman Antiquity, 154-168.

VeYne 2016: P. Veyne, La Villa des mystères à Pompéi, Paris 2016.

VEYNE et al. 1998: P. Veyne et al., Les mystères du gynécée, Paris 1998.

WHITEHOUSE 2004: H. Whitehouse, Modes of Religiosity. A Cognitive Theory of Religious Transmission, Walnut Creek 2004.

ZAMAGNI 2018: C. Zamagni, «The Elenchos and the 'Mysteries'. Constructing Heretical Identity in Ancient Christianity», RRE 4 (2018), 289-302.

ZANKER 1988: P. Zanker, The Power of Images in the Age of Augustus, Ann Arbor 1988.

\section{NOTES}

1. Plutarch, fr. 157 Sandbach, 15-25 (On the Festival of the Images at Plataeae), transl. F. Sandbach.

2. I warmly thank Claudia Beltrão and Federico Santangelo for their invitation, their incomparable hospitality, and many thoughtful discussions ... not to mention the careful correction of the English form.

3. See BÉRARD et al. 1984 (Engl. transl. BÉRARD et al. 1989).

4. See ZANKER 1988; HÖLSCHER 2004 and 2018; ELSNER 2007.

5. BECK 2006, 24.

6. Consequently it addresses neither the many pending issues pertaining to the Roman cult of Mithras nor its contradictory interpretations, except when images are concerned.

7. See BeLAYCHE, MASSA 2021a.

8. See e.g. TURCAN 1993, 45: "Le mithriacisme nous est accessible surtout et directement par l'iconographie" (italics mine), and infra n. 14.

9. See F. Cumont's letter to A. Loisy on August 7, 1909: "Vous trouverez quelques indications réunies dans les Monum. Myst. de Mithra, I, p. 324-5 avec les renvois nécessaires. Vous verrez que c'est maigre" (italics mine). See cLAuss 2001 (first German ed. 1990), 102: "Rather oddly, initiation 
is one of the aspects of the mysteries of Mithras the literary sources do not mention". On the epigraphical evidence, see BELAYCHE forthcoming.

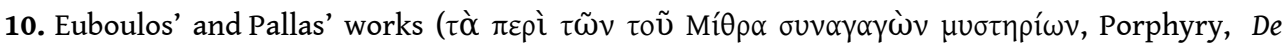
abstinentia $2,56,11$ ) possibly through Numenius: see TURCAN 1975, 23-43.

11. C UMONT 1899, 53. Cumont had a "Winckelmannian" approach to iconography: see the appendix on "l'art mithriaque" in CUMONT 1913, ed. 2013, 221-238. There is no need to recall the foundational place of F. Cumont as the initiator of Mithraic studies; see a letter of A. Loisy (July 31, 1909): "C'est vous qui êtes Mithra".

12. CUMONT 1899, XII.

13. BONNET 1997.

14. Cumont 1913, Les Mystères de Mithra, p. 101 (italics mine) and 172: "représenter sur la pierre non seulement les divinités, mais la cosmogonie des mystères et les épisodes de la légende de Mithra jusqu'à l'immolation suprême du taureau". For TURCAN 1993, Mithraic images are "de véritables 'histoires saintes' en images", with a Christian flavour in the expression. See also BREMMER 2014, 131, who designates the birth of Mithras (from the rock) as "a kind of 'immaculate conception"".

15. For a recent critique of this method see BECK 2006, 17-25; see also ADRYCH et al., 2017, 9-10, with a valuable emphasis on the point that many Mithraic reliefs had been restored along a modern (Cumontian) model of the Mithras mysteries, and these restorations corroborate a debatable reconstruction (19-24).

16. The first known dated relief (CIMRM 594), that of Alcimus, a slave vilicus of the Praetorian Prefect Ti. Claudius Livianus, was dedicated c. 102 Sol(i) M(ithrae). CAMPBell 1968, 291-293, also focusing on the tauroctony reliefs and frescoes, reads "some form of an initiation rite", telete (laying on of hands; pouring on of water; purification) in scenes from predellas; for the Capuan frescoes see infra.

17. C UMONT $1927^{4}$ [2006], 5, read the Zend Avesta as a literal account, a "commentaire pour interpréter la masse considérable de monuments figurés" (italics mine).

18. See e.g. Clauss 2001, 102: "the fancifulness of [the Christian] accounts of the supposed tests of courage growths with their date of composition".

19. On philosophical texts, see the caveat of VAN NuffeLEN 2011, 47: "the fact that we are dealing with philosophical reinterpretations of mystery cults should warn us against naïvely using descriptions of mystery cults by philosophers as unequivocal evidence for their real functioning". This point was demonstrated by TURCAN 1975.

20. Cf. e.g. the mithraea of Felicissimus and of the Sette Sfere in Ostia. GORDON 1996, 20, initiated the reading of the grades as "modelled upon the structure of the cosmos".

21. For a definition of the term, B IANCHI 1965, esp. 155: "nous entendons par 'initiation' l'accession rituelle d'un individu ou d'un groupe homogène dans un état, ou plus spécifiquement, dans un corps sacralement qualifié et religieusement 'autre"'. On the intersection between rites de passage and initiations, see GRAF 2003.

22. Cf. CHALUPA 2008 and ADRYCH 2021. I concur with ALVAR 2008, who, after devoting eight pages to the grades, states: "I think it more realistic to discuss Mithraic initiation not primarily in terms of the grades" (371).

23. Aelius Aristides, 'E $\lambda$ zuoívioৎ (Or. 22), 2.

24. See e.g. MARTIN 2006, based on the theorical model of WHITEHOUSE 2004.

25. For the mysteries of Mithras, BOWDEN 2010, 181-197; MARTIN 2015; PANAGIOTIDOU-BECK 2017. On mithraea as space, GORDON 2017.

26. Cf. SIMMEL 1950. 
27. See also the case of Ephesos, where the $\mu$ group of ritual agents who seem to be involved in regular ritual gestures, opposite to their mystike performance at Mount Solmissos: see BELAYCHE 2016.

28. GORDON 1996 and BECK 2006.

29. See the debate on the interpretation of the frescoes of the so-called Villa of the Mysteries (Villa Item) at Pompei (70-60 BCE): some scholars interpret them as displaying a Dionysiac initiation (e.g. SAURON 1998), while others argue for the sequence of a wedding ceremony displayed in the Roman matron's apartments (VEYNE ET AL. 1998, 13-153 and VEYNE 2016).

30. BURKERT 1987.

31. For the "mystericization" in the second century CE, see BELAYCHE, MASSA and HOFFMANN 2021.

32. See BELAYCHE 2006, 2008, 2017 and 2021a.

33. AnHiMA (UMR 8210, Paris), "Les 'cultes à mystères' (mystèria, teletai, orgia, etc.) et leurs acteurs spécialisés” (2014-2018), https://www.anhima.fr/spip.php?article1164, last accessed 15.04.21.

34. Cf. BELAYCHE-MASSA 2021b.

35. Cf. F. Cumont's letter to A. Loisy (August 7, 1909) on the mysteries of Mithras: "Rien de plus mystérieux que le rituel de ces mystères".

36. For instance that of Neuenheim (today in the Museum of Karlsruhe): CIMRM II, 1289. The precursor of a post-Cumontian and astronomic reading is GORDON 1996. The approach was further developed in BECK 2006. On the use of these images, see recently MASTROCINQUE 2017, who builds his "different account" (an Augustan propaganda discourse) upon them. On the tauroctony and the methodological problems that its reading presents, see ADRYCH ET AL. 2017.

37. ALVAR 2008, 351-358, studies the common meals with sacrifices as "a communicative institution" (355)

38. Yet R. Beck proposed to combine the two readings on the Mainz krater. See infra n. 92.

39. Too long to be quoted in extenso: see firstly the foundational reexamination in BURKERT 1987; COSMOPOULOS 2003; BOWDEN 2010 (with a cognitivist approach); BREMMER 2014, with light focus on images, 135-137.

40. See e.g. Blakely 2009; Martin-Velasco-Garcia 2016; Belayche-Massa 2016; PhilonenKo-LehmanNPERNOT 2017.

41. B ECK 1998 convincingly proposed that they might have been invented within Roman astrological circles, like that of the Balbilli, connected both to Commagene and Egypt, and possibly familiar with Chaldaean magi that came to Rome with the king Tiridates of Armenia during the reign of Nero, see Pliny, Natural History 30, 6, 1. Under Domitian, see Statius, Thebaid, 1, 719-720: Persei sub rupibus antri/indignata sequi torquentem cornua Mithram ("Mithras, that beneath the rocky Persean cave strains at the reluctant-following horns", transl. LCL).

42. CumONT 1913 [2013], 29. Nevertheless scholars still read them through the Greek model, e.g. BREMMER 2014, 133 : "the inventor of the Mithras Mysteries may well have been influenced by the fact that the Eleusinian and Samothracian Mysteries had only two grades".

43. Considering the loss of Euboulos' work (see supra n. 10), this categorization goes back to the Christian authors of the second half of the second century (Justin, Tertullian, etc.): MASSA 2016. Some reflections on its significance in ALVAR 2008, 6-14.

44. He equated them with "Oriental religions": "Toutes les dévotions venues du Levant ont pris la forme de mystères" (2006, XXXIX-XLIV). SFAMENI GASPARRO 2003, 130, goes as far as arguing that the mysteries of Mithras were the model of "mystery" because of their complete secrecy: "Solo per il mitraismo sarebbe legittimo usare la definizione di 'religione di mistero"'.

45. On Mithras see now Alvar 2008, 74-106, "who essentially resumes Cumont" (78), but with a focus on new astronomic insights. 
46. CUMONT $1927^{4}$ [2006], 44-67. This theme was at the core of the conference held in Rome in 1979, whose proceedings were published as BIANCHI-VERMASEREN 1982, with many contributions that argued for a conception of this-wordly salvation.

47. See BonNet-RüPKe-SCARPI 2006 and BonNet-PiRenNe-Delforge-Praet 2009. On the mysteries of Mithras, see BELAYCHE-MASTROCINQUE, "Introduction historiographique”, in CUMONT 1913 [2013], XIIILXXXVIII.

48. See infra n. 90-92.

49. Cf. e.g. MAAR-BURDA 2004; STIEGLER 2008; BRÄUNLEIN 2009; BÉRARD 2018, esp. 15-35 ("Iconographie Iconologie - Iconologique").

50. For instance on images of gods: see MYLONOPOULOS 2010, 201 and ESTIENNE et al. 2014.

51. See BeLAYCHE-MASSA 2016, 7-19.

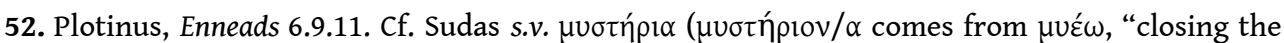
lips or eyes") See MotTE 1986 and Montiglio 2000, 23-31 (“Closing One's Lips, Closing One's Eyes: Silence in the Initiation into the Eleusinian Mysteries").

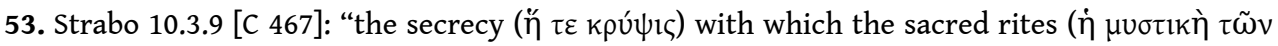

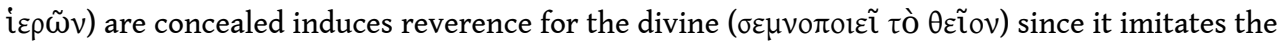

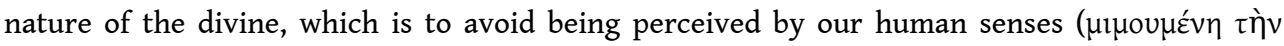

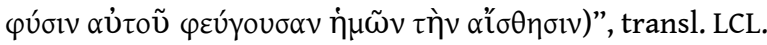

54. We have only one epigraphical "report" of these meetings (in fact a poetic text by the Father Proficentius), which does not allude to religious considerations, but to the joyful conviviality of the syndexi: CIMRM 423; cf. BELAYCHE forthcoming. The point is confirmed by the types of ceramics found within excavated mithraea: see e.g. KLENNER 2019, 307 and 381.

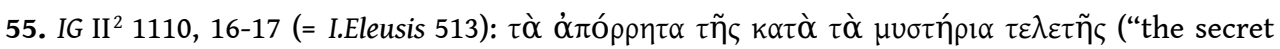
rites of the initiation during the Mysteries").

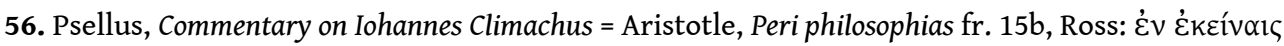

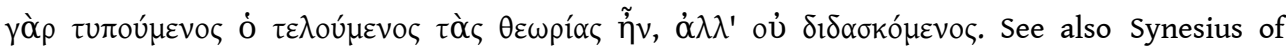
Cyrene, Dion 8, 5-8 = Aristotle, Peri philosophias fr. 15, Ross: oủ $\mu \alpha \theta \varepsilon \tilde{\imath} v$ [...] $\dot{\alpha} \lambda \lambda \grave{\alpha} \pi \alpha \theta \varepsilon \tilde{v} v$.

57. This does not disregard the fact that books may have also been used during the ceremonies: for the Dionysiac mysteries see MASSA 2013.

58. Sopater, Rhetores Graeci, 8, p. 115 (ed. Walz), transl. BURKERT 1987, 90.

59. See BELAYCHE 2021b.

60. These features are displayed from Plato onwards, infra n. 75. See U STINOVA 2017, 113-168

("Telestic mania and near-death experience") who takes for granted ancient textual evidence.

61. Ps.-Demetrius of Phaleron, On Style, 101.

62. Plotinus, Enneads, 5, 1, 7, 33 (on the generation from Cronos); for Eleusis, Clement of Alexandria, Protrepticus. 2, 12, 2 (the abduction of Persephone and the wandering of Demeter). See NILSSON 1953, 180: "Mystery rites were, when represented, generally concealed in a mythical guise". Mysteries were so strongly connected with a pathway to truth that hidden discourses were presented as full of truth: "a suggestion of truth": VAN NUfFELEN 2007.

63. Clement of Alexandria, Proptrepticus, 2.13.1, quoted by Eusebius of Caesarea, Preparation for the Gospel 2.3. 9-10 (transl. LCL), in a section entitled "On the unspeakable rites and the secret

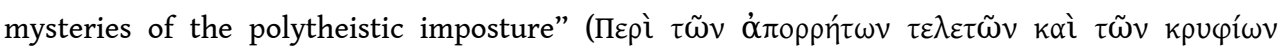

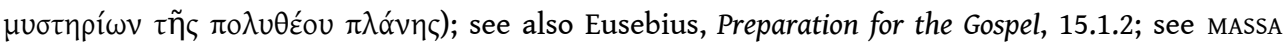
2016 and 2018.

64. TALGAM-WEISS 2004.

65. BELAYCHE-MASSA 2021b, 7-22.

66. Plutarch, fr. 157 Sandbach, 15-25 (On the Festival of the Images at Plataeae), ap. Eusebius, Preparation for the Gospel, 3, Prooem. For mystery-like discourses on the philosophical progression, Roskam 2001 and MARTin-Velasco-García BLANCo 2016. 
67. Plutarch, On Talkativeness 7.505F.

68. See MASSA 2018 and VEYMIERS 2021.

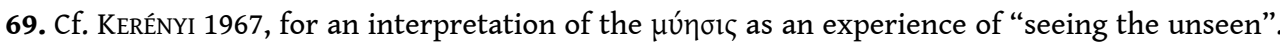
See also SABBATUCCI 1965, 147 on Eleusis ("luce, visione dell'alterità [...], illuminazione [...], salvezza futura"); CLINTON 2003; and PETRIDOU 2013.

70. IG II $^{2} 3764$ (in 217/218); see also 3662, 5 (end of the second-beginning of the third century).

71. Cf. IG II 3639 and 3411 (the hierophant who initiated the emperor Commodus).

72. Varro, quoted by Augustine, Civ. D. 7.20. In Mithraic rituals tradere is the regular verb for expressing initiation or the grant of a new grade: CIMRM 400-405, from 357 to 376 CE in Rome.

73. Ps.-Hippolytus, Refutatio omnium haeresium, 5.8.39. See ZAMAGNI 2018, 298-299 on this passage.

74. IG II $^{2} 3661,3-4$ (end of the second-beginning of the third century). In literature, see Euripides,

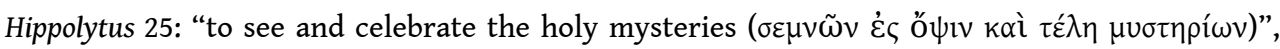
transl. LCL; Andocides, On the Mysteries, 31: "you are here as initiates who have seen the rites of

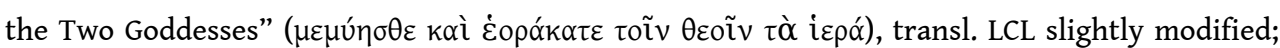
and so on.

75. Plato, Phaedrus, 250bc and 265b, and Aristotle, Peri philosophias, fr. 15b, Ross (quoted by

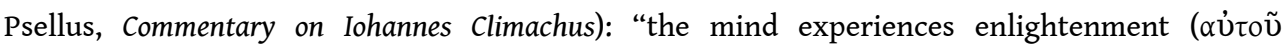

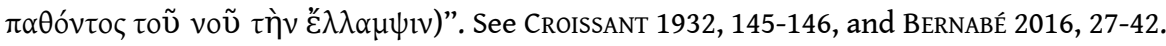

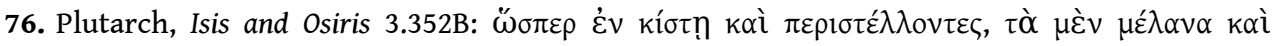

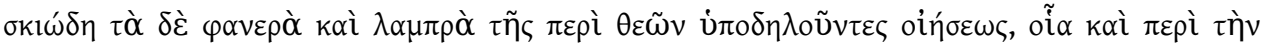

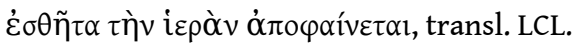

77. The Eleusinian formula ( Protrepticus 2.21.2, points to it: "I fasted, I drank the kykeon, I have taken from the chest, I worked

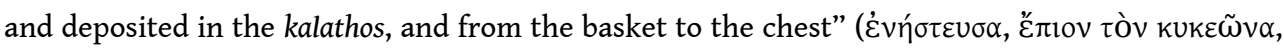

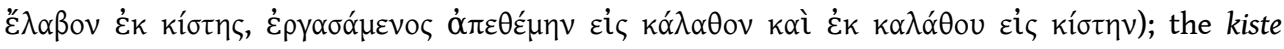
supported some kind of manipulation by the mystai, before becoming a visual marker, see infra $n$.

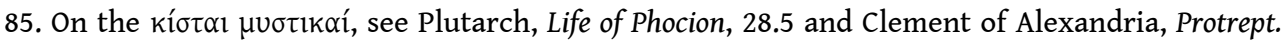
2.22.4.

78. Plutarch, Isis and Osiris 27, 361E, transl. LCL.

79. Pausanias 1.38.7; see CLINTON 2003.

80. Cf. Lucian, The Parliament of the Gods 11.1-6: $\alpha$ iví $\gamma \mu \alpha \tau \alpha$ revealed to initiates during mysteria; and supra n. 77.

81. It may be noted that Porphyry, On Abstinence 4.16, states that those who receive the Lion

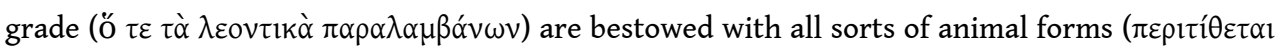

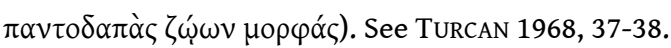

82. Respectively: CIMRM 1896 fig. 491 rev.; Ambrosiaster, Quaestiones veteris et novi Testamenti 114.11: "Certains battent des ailes comme des oiseaux et imitent le cri du corbeau, d'autres au contraire rugissent à la manière des lions" (transl. Sources chrétiennes 512); CumONT 1899, 8. See BURKERT 1987, 93: "More graphic and hence less likely to reproduce mere fantasy". But GORDON 2019,469 rightly doubts that it was an actual banquet of worshippers.

83. See e.g. BÉRARD-BRON-POMARI 1987.

84. Cf. GORDON 1996, 46: "the opacity of iconography".

85. See supra n. 76. Images of kistai, torches, wheat, and other objects related to the cult of Demeter were publicly displayed on the main buildings of the sanctuary: MYLONAS 1961, fig. 55-57. For images of kistai/baskets on Attic votive reliefs, see HAMILTON 2009.

86. Considering that it is not a traditional Egyptian object, one may wonder if the Graeco-Roman Isiac worshippers borrowed it as an actual ritual object or in order to visually endow their cult with a mystery-like image, and thus vest their foreign and new cult with respectability.

87. See respectively the papers by JACCOTTET 2021, VAN HAEPEREN 2021, and VeYMIERS 2021. 
88. Mithras himself can yield a torch: see the relief on an altar from Apulum (Brukenthal National Museum, Sibiu, inv. no. 7274). Moreover, there was a practical necessity in the dark mithraea.

89. See VERMASEREN-VAN ESSEN 1965, 160-162 (the East wall); recently see MoORMANN 2011, 163-183. In the mithraeum of Dura too the grades are acclaimed (CUMONT 1975): however, this says nothing about the initiation ritual stricto sensu. The remarkable archaeological study of the Mithraeum II at Güglingen - a valuable comparandum because of its rigorous methods - attests to sacrifices only and rejects the spatial possibility of processions, KLENNER 2019.

90. MinTo 1924. For the frescoes see CAMPBELl 1968, 294-300 and VERMASEREN 1971, 24-51, with a synoptic chart of the successive panels at 25 fig. 5 . More recently a detailed study by GoRDON 2009, with 296 fig. 16.3: "a schematic representation of the arrangement of the scenes on the podium frescoes".

91. B ULL et al. 2017. This final report presents significant differences with the preliminary reports, which are now outdated.

92. Dated to 120-140 CE (Mainz, Archäologische Denkmalpflege Inv. FM 83-101); BECK 2000 and HULD-ZETSCHE 2008.

93. GoRDON 2009, on the basis of the Capuan frescoes, argues that Mithraic identity and teaching were transmitted through the suffering body in a "théâtre de la terreur" (M. Foucault); his parallel with Christian martyrs is less convincing.

94. This is the case with the Eleusinian model, but the Mithras cult has its own genesis.

95. The Isiac model built after Apuleius, Metamorphoses XI, is not relevant, because the three initiations of Lucius concern two different places and two different deities.

96. See e.g. CLAUSS 2001, 102-105, and AlVAR 2008, 346-349 and esp. 371-376. On the procession, see BECK 2006, 123-133 and 2008, 154-157, who puts forward the hypothesis of a symbolical representation of the astronomical solar journey.

97. VERMASEREN 1971, 48: "any of the descriptions in the ancient authors concerning initiations in the Mithraic mysteries are really useful for the interpretation of these unique Capuan frescoes".

98. VERMASEREN 1971, 38-39 (italics mine). Tertullian, De corona 15.3-4: "some soldier of Mithras, who, at his initiation in the gloomy cavern, in the camp, it may well be said, of darkness, when at the sword's point a crown is presented to him, as though in mimicry of martyrdom, and thereupon put upon his head, is admonished to resist and cast it off, and, if you like, transfer it to his shoulder, saying that Mithras is his crown. etc." (italics mine). In the recently published Mithräum II from Güglingen (Germany), KLENNER 2019, two swords ("die Deponierung des Kultschwertes aus dem ersten Tempel unter dem Fundament des neuen Altares", 143 and 251-257, "Theaterschwert"?), a bow and arrows ("Reflexbogen", 257-258) and a rayed iron crown ("Strahlenkrone", 259-261) are interpreted as artefacts for the initiatory ritual; for Tertullian, 368-369 ("ergibt sich, daß die Archäologie hier die Schriftquellen bestätigen kann"). See also HENSEN 2013, 65, for the theatrical sword of the Riegen mithraeum. I do not need to delve here on the discussion of signare frontibus, see Renaut 2007.

99. VERMASEREN 1971, 41: "it is with this statement as a starting point that one must try to explain Tertullian's difficult text". The imitatio diabolica is a current Christian pattern: see MASSA 2016.

100. VERMASEREN 1971, 40 ("the second part of the text gives a further comment").

101. See also CAMPBELL 1968, 292-293, who interprets a motif of the tauroctony reliefs as a "coronation" in the Telete related to the Heliodromus.

102. See GORDON 2009, 300. The figure is already wearing a Phrygian cap: CAMPBELL 1968, 300.

103. Tertullian, De praescr. haer. 40.4 .

104. Vermaseren 1971, 42. 
105. For CAMPBELL 1968, 297, “a ceremonial slaying of the initiate" on the model of Mithras' slaying of the bull; he calls into play SHA Commodus 9.5 - yet the anecdote might be in keeping with the portrait of a "bad emperor".

106. VERMASEREN 1971, pl. XXVI.

107. See e.g. Ambrosiaster, Quaestiones veteris et novi Testamenti 114.11: “On leur voile les yeux [...] d'autres encore, les mains liées par des boyaux d'animaux, sont poussés au-dessus de fosses remplies d'eau, lorsque arrive quelqu'un armé d'un glaive, rompant les susdits boyaux, qui se proclame libérateur" (transl. Sources chrétiennes 512).

108. See the following note. Cf. AlVAR 2008, 371 ("to underline the role of fear, submission and endurance in Mithraic rituals of this type") and 373 ("these scenes imply fear and suffering as an essential part of Mithraic initiation").

109. Aelius Aristides, Orations 50 (Sacred Tales 4), 7. See the well-known fragment of Plutarch, De anima (fr. 178 Sandbach), ap. Stobaeus, 4.52.49: "The soul suffers as do those who have been

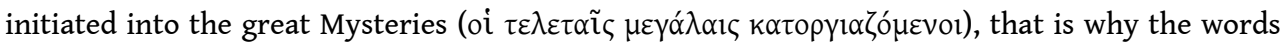
and the actions of dying ( $\tau \varepsilon \lambda \varepsilon v \tau \tilde{\alpha} v)$ and performing the rituals ( $\tau \varepsilon \lambda \varepsilon \tilde{i} \sigma \theta \alpha \mathrm{l}$ ) resemble each other.

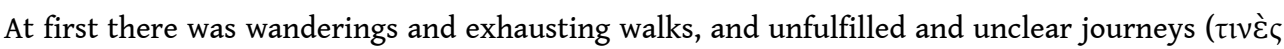
Ǔ

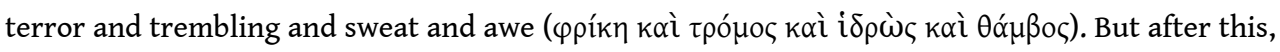
a marvelous light ( $\varphi \tilde{\omega} \varsigma \tau \iota$ Ө $\alpha u \mu \alpha ́ \sigma ı v)$ appears ..."

110. GORDON 2009, 303: "a structure of oppositions".

111. ELSNER 2003, 126.

112. Other proposals of identification of the grades can be only hypothetical in absence of their visual markers, like those known from the mithraeum of Felicissimus in Ostia, whatever view one might take in the debates on their meaning: see GORDON 2013.

113. Already by the first editor H.G. Horn (HORN 1994, esp. 25-28); then, e.g., BECK 2008, 149-150 and AlVAR 2008, 348-349: face A depicts "a Pater and a Heliodromus, namely representatives of the two highest grades, endorsing the promotion of a worshipper to the inferior grade Miles, followed by a mystagogue, i.e. the man responsible for accompanying and protecting the initiate."

114. ВЕСК 2008, 148.

115. See supra n. 61

116. ВЕСК 2008, 149-154.

117. See GORDON 2009, 297 ("tests were not standardized between temples, and each Mithraic community devised its own forms of initiation") and GORDON 2019, 466-467.

118. See BELAYCHE, MASSA 2016b and BeLAYCHE-MASSA 2021a.

119. BULL ET AL. 2017.

120. MOORMANN 2011, 182; GORDON 2001, 80. Both scholars made comparisons with the Capuan frescoes and the Mainz vessel.

121. The illumination of the room on the Summer solstice (BULL ET AL. 2017, 61-62) is fascinating. Yet it is probably a fantasy, because the mithraeum was settled in a vaulted room beneath a portico, thus with no opening towards the sky: BURRELL 1993.

122. CAMPBELL 1968 proposed a typology.

123. See ELSNER 2003, 127: "a single and recognizable empire-wide form of Mithraism or to the desire of various ad hoc sects and groups to aspire to a vision of unity while in fact practising and believing whatever they liked."

124. See BARATTE 2001 and GAWLIKOWSKI 2007. We can also recall the iconographic diversity in the Ostian mithraea.

125. BulL ET AL. 2017, 47: “Taken together, the three panels represent an initiation". 
126. BULL ET AL. 2017, 44: "The elements of this scene depict a procession. The composition has parallels to known images of initiation practices (Sta Maria Capua Vetere, Konjic) and should therefore be interpreted as a scene from an initiation ritual".

127. The editors acknowledge the point at 44: "processions as part of the preparation for the cult meal and ritual". See on Güglingen KLENNER 2019, 377-386.

128. See supra n. 54. ELSNER 2003 stresses the use of art as a means "to help establish a more coherent sense of community and identity among existing members" (125).

129. The distinction between the various stages is made through the change of garments: see GAWLINSKI 2012.

130. BULL ET AL. 2017, 45-46.

131. Tertullian, Against Marcion 1.13.5: sicut aridae et ardentis naturae sacramenta leones Mithrae philosophantur. The verb itself prevents a literal use of the passage. Contra KLENNER 2019, 376 ("diese Feuerprobe").

132. Porphyry, On the Cave of the Nymphs 15 (transl. R. Lamberton, New York, 1983, with slight changes); see also 17 (passim): “Étant donné donc que le miel est utilisé pour purifier, pour protéger de la corruption et pour donner le plaisir qui attire vers la génération $(\Lambda \alpha \mu \beta \alpha v o \mu \varepsilon ́ v o v$

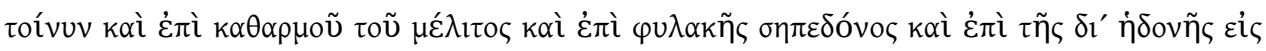

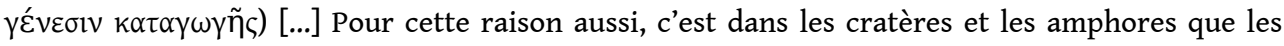
abeilles déposent leur miel, car les cratères portent le symbole des sources [...] tandis que les

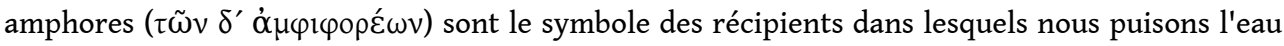
qui vient des sources." (transl. T. Dorandi, Paris, 2019).

133. Porphyry, On the Cave of the Nymphs, 17: "just as a krater is set beside Mithras to stand for a

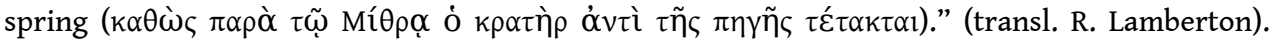
There is a strong scholarly consensus on considering Porphyry's information as second hand. See AKÇAY 2019, 64: "we cannot disregard the view that Porphyry (and Eubulus) offer their own Platonising interpretation of scraps of information picked up at second or third hand about the mysteries".

134. The point has been closely studied, from LAMBERTON 1986 to AKÇAY 2019.

135. Bull ET AL. 2017, 46.

136. See BELAYCHE 2009.

137. Cf. I.Stratonikeia 22, 23, 25, 27, 30. LAUMONIER 1958, 255, stresses the "fête-beuverie".

138. KLENNER 2019, 153 ("Für die Mithräumsdecke wählte man also nicht spezifisch sakrale Themen, sondern durchaus beliebte, profane Muster") and 161 ("Entgegen der allgemeinen Vorstellung, Mithräen wären im Inneren mit Sternenhimmeln bemalt gewesen, orientierte man sich mit der Wahl der Dekoration eher an den für die Wohnkultur der Zeit üblichen Motiven").

139. See MASSA 2017.

140. Some answers will be put forward in a forthcoming monograph: F. MASSA, Les cultes à mystères dans l'empire romain : païens et chrétiens en compétition.

\section{ABSTRACTS}

This paper starts with a preliminary reflection on the broader field of "mystery cults", which are characterized by a ban on divulgation and the incommunicability of experience. The "mysteries" of Mithras present a further difficulty: their images, built within Roman contexts, lack the visual 
markers of the Greek "mystery cult" tradition. Moreover, the epigraphical evidence for the worshippers of Mithras does not mention "mysteries". The second and longer section of the paper addresses the few frescoes that were interpreted as depictions of initiation rituals inside three mithraea and on an adorned krater. It first recalls the main approaches to the interpretation of these images (historiography, anthropological approach, semiotic reading), and then argues that these images intended to display to the viewers (insiders/initiates) a sense of grouping and of contrasted agencies within the groups, to different extents in each mithraeum. By focusing on a case-study from Caesarea Maritima, it proposes to identify the three different ways through which a religious group might give an image both of itself and to itself: a collective ritual (i.e. a procession), the initiation as a transmission (without a special terrifying ambiance), and a mythological narrative on the deity who protects the group.

Questo articolo prende le mosse da una riflessione preliminare sui "culti misterici", significativamente marcati dal divieto di divulgazione e dall'incomunicabilità dell'esperienza. I "misteri" di Mitra presentano poi un'ulteriore difficoltà: le loro immagini, costruite in contesti romani, mancano di quei marcatori visivi che pertengono alla tradizione dei "culti misterici" greci. Inoltre, l'evidenza epigrafica non menziona "misteri" in relazione ai devoti di Mitra. La seconda e più ampia parte dell'articolo esamina le poche testimonianze che sono state interpretate come raffigurazioni di riti di iniziazione all'interno di tre mitrei e su un cratere decorato. Riprende poi, in primo luogo, i principali approcci interpretativi proposti per la lettura di queste immagini (dal punto di vista storiografico, antropologico e sociologico), per passare a individuare in esse l'intento di alimentare negli spettatori (insiders/iniziati) il senso di comunità, dando la misura delle diverse forme di agentività attive all'interno del gruppo e in maniera differente tra un mitreo e l'altro. Attraverso l'analisi del caso studio di Caesarea Maritima, il contributo identifica tre differenti modalità attraverso cui un gruppo religioso può restituire, nello stesso tempo, un immagine a se stesso e di se stesso: il ricorso a un rituale collettivo (cioè una processione); l'iniziazione intesa come trasmissione (senza ricorso ad atmosfere particolarmente spaventose); e, infine, una narrazione mitologica sulla divinità che protegge il gruppo.

\section{INDEX}

Keywords: initiation, images, mystery cults, Mithraism, Caesarea Maritima, Cumont Franz Parole chiave: iniziazione, immagini, culti misterici, Mitraismo, Caesarea Maritima, Cumont Franz

\section{AUTHOR}

\section{NICOLE BELAYCHE}

EPHE, PSL, Paris - AnHiMA, UMR 8210

INHA, 2 rue Vivienne,

75002 Paris, France

n.belayche(at)ephe.psl.eu 